\title{
Iranian Language Teachers' and Students' Perspectives on Top Notch Series (2nd edition) at Intermediate Level
}

\author{
Mehdi Azadsarv (Corresponding author) \\ Department of TEFL, Rasht Branch, Islamic Azad University, Rasht, Iran \\ E-mail: Arasazadsarv@gmail.com \\ Abdorreza Tahriri \\ Department of English Language, University of Guilan, Iran \\ E-mail: atahriri@gmail.com
}

Doi:10.7575/aiac.alls.v.5n.6p.84

Received: 05/08/2014

URL: http://dx.doi.org/10.7575/aiac.alls.v.5n.6p.84

Accepted: 02/10/2014

\begin{abstract}
As the means of transferring knowledge between teachers and students, coursebooks play a significant role in educational practices all over the world. Evaluation of coursebooks is also of great significance as it manages to a better understanding of the nature of a specific teaching/learning situation. The present study is an attempt to evaluateTop Notch coursebook from both Iranian EFL learners' and teachers' perspectives. One hundred students and 20 teachers participated in this study. Sixty four of the students and nine of the teachers were male and 36 of the students and 11 of the teachers were female. The range of teachers' experience of teaching the coursebook was between 2-4 years and the range of students' experience of studying the coursebook was between 1-3 years. The data collection took place in three language institutes of Gilan and Mazandaran provinces. The coursebook, evaluated based on modified version of Cunningsworth's (1995) checklist, was the intermediate level of Top Notch. It was evaluated by both students and teachers based on administering written questionnaires. In order to triangulate the gathered data, 25 percent of the teachers and 10 percent of the students attended an interview session. Data analysis indicated that strengths of Top Notch from teachers' perspective are grammar, visuals, supplementary materials and culture and from students' point of view are content, grammar, phonology and visuals.
\end{abstract}

Keywords: coursebook, checklist, evaluation, Top Notch

\section{Introduction}

In the process of language teaching and learning, several components are involved in such as the learners, the teachers, the environment in which the learning event is taking place, the purpose of learning, and more importantly the textbooks, since they undoubtedly specify the main part of the teaching in the classroom and out-of-class learning of the students. Hutchinson and Torres (1994) state no teaching-learning situation is complete without adopting its appropriate textbook. Materials and textbooks serve as one of the main instruments for shaping knowledge, attitudes, and principles of the students (Nooreen\& Arshad, 2010).

Today, coursebooks are of vital significance to educational practices all over the world since they serve as the means of transferring knowledge between teachers and students. In addition, they are considered as the basis for much of the language input and the language practice which learners receive in the classroom. As Richards (2001) states, for learners the textbook might provide the main source of contact they maintain with the language. Litz (2005) asserts that whether one believes textbooks are too inflexible and biased to be used directly as instructional material, there can be no denying that they are still the most valuable element in educational systems. Garinger (2002) believes that a textbook can serve different purposes for teachers: as a core resource, as a source of supplemental material, as an inspiration for classroom activities, and even as the curriculum itself.

As a relatively new trend in the field of English language teaching (ELT), coursebook evaluation has attracted many language scholars' and curriculum developers' attention. Coursebooks have to be evaluated, since they are the basic materials in the learning process. The aim of textbook evaluation was to develop checklists based on which a book could be analyzed in detail in order to assure its usefulness and practicality with such factors as proficiency level of students, learners' needs, course objectives, gender, and many other contextual factors. (NajafiSarem ,Hamidi, \&Mahmoudie, 2013)

Tomlinson (2001) proposes coursebook evaluation is an applied linguistic activity through which teachers, supervisors, administrators and materials developers can make judgments about the effect of the materials on the people using them. Kiely (2009, p. 105) asserts that evaluation attempts to ensure "quality assurance and enhancement" and constructs "a dialogue within programs for ongoing improvement of learning opportunities." McGrath (2002) holds that coursebook evaluation is also of a significant value for the development and administration of language learning programs. 
Therefore, evaluating coursebooks in order to see whether they are suitable is of crucial significance.

Sheldon (1988) states coursebooks are the visible heart of any ELT program for both teachers and students; however, they are not free from shortcomings. Litz (2005) asserts that having dissatisfied textbook is due to the fact that they are often considered as the "tainted and product of an author's or a publisher's design for quick profit" (Sheldon, 1988, p.239).

Coursebooks are considered as significant resources for teachers and instructors in helping learners learn every subject including English. Finding an English institute without a coursebook is something surprising in Iran. Even some people compare different institutes and different teachers based on the coursebook they use in their English classes. Iranian students depend heavily on coursebooks and learn materials in a way that are displayed in their coursebooks; therefore, the content of textbook outweighs anything else.

Textbooks do not only influence what and how students learn, but also what and how teachers teach. Few teachers teach without a textbook that offers content and activities that form much of what occurs in a class. Nowadays textbooks play a very vital role in the dominion of language teaching and learning. In addition, after teachers, textbooks are considered to be the next significant aspect in the foreign language classroom. As Hutchinson and Torres (1994) believe, the textbook is an almost worldwide component of English language teaching. Millions of copies are sold yearly, and many aid plans have been set up to produce them in different countries.

McDonough and Shaw (2003) believe that there are several circumstances that it is needed to evaluate textbooks. The first is when the teachers might be given the choice to adopt or develop their materials and the second is when they are just users of other people's products. In both of these circumstances, some degree of evaluation is necessary. In EFL settings it can be discussed that the teacher and the textbook are the two most significant and immediate cultural links between the student's innate culture and the target foreign culture. If the dominant roles of the teacher and the textbook are accepted, then the way the textbook portrays the role of several people in the target society and the way they use language to express their meanings directly affect EFL students' choices of language when communicating with native speakers. Therefore, the materials and textbooks of each era in the history of ELT reflect the ethics and philosophies of a teaching method which were trendy at that time.

According to Sheldon (1988), we need to evaluate textbooks for two reasons; first, the evaluation will help the teacher or program developer in making decisions on selecting the appropriate textbook. Furthermore, evaluation of the merits and demerits of a textbook will familiarize the teacher with its probable weaknesses and strengths. This will enable teachers to make appropriate adaptations to the material in their future instruction.

Therefore, the present study is an attempt to address the issues mentioned above by determining the overall pedagogical value and suitability of the Top Notch coursebook from both Iranian EFL learners' and teachers' perspectives.

This study seeks answer to the following questions:

1. How is Top Notch series viewed from language teachers' and students' perspectives?

2. What are the strengths and weaknesses of Top Notch series?

\section{Review of Literature}

English language teaching consists of significant components among which coursebooks and instructional materials are of vital importance in EFL/ESL classes and courses and are often employed by language teachers. Coursebook is a universal constituent of English language teaching. In ELT, coursebooks have always been one of the most preferred instructional resources. They are best viewed as a material in achieving goals and aims that have already been set concerning learner needs (Cunningsworth, 1995). In spite of the development of new technologies which makes highquality teacher-generated materials possible, a need for coursebooks grows every day, and new series of coursebooks are published every year (Lamie, 1999).

Ur (1996) defined coursebook as a textbook of which the teacher and, usually, each student has a copy, and which is in principle to be followed systematically as the basis for a language course. It also provides a clear framework. She proposed that coursebooks clarify subsequent materials and learners know where they are going. Due to having readymade texts and tasks, coursebooks save the time of the teacher. In addition, it guides the inexperienced teachers. Ur added that a textbook could provide the learner with some degree of autonomy. In other words, a learner without a textbook becomes more teacher-dependent.

In addition, coursebooks have a significant role to play in language classes in all educational settings: public schools, universities, and language schools. Razmjoo (2007) stated that working with a coursebook gives most students a sense of progress and achievement. Coursebooks are identified as an ineffective resource for self-directed learning and an effective resource for teacher-directed learning. Moreover, they are considered as a source of ideas and activities, a reference source for students, a syllabus that reflects predetermined learning objectives. They also serve as a support for the beginning teachers who have yet to gain in confidence (Cunningsworth, 1995). Therefore, it can be concluded that the basic role of coursebooks is to be at the service of teachers and learners but not their boss.

According to Daoud and Celce-Murcia (1979), it is useful to know some information on coursebook selection as sometimes it is teachers' duty to choose a coursebook which is going to be taught in a class. This selection should not be arbitrary; rather, it has to be careful and systematic. They also stated that even in places where teachers are not directly involved in coursebook selection, they might be asked to give reports on the effectiveness of the coursebooks they are already taking advantage of. Several criteria for selecting an appropriate coursebook have been offered although 
carrying out a sound selection of appropriate coursebooks is not a fully objective process. In spite of various guidelines which are offered, teachers' subjective judgments are central to coursebook selection. In materials selection, the materials have to be matched with goals and objectives of the program, and it is important to make certain that they are in line with one's beliefs about the nature of language and learning, as well as with one's learners' attitudes, beliefs, and preferences (ibid.).

Coursebook evaluation is an approximately new phenomenon in language teaching field. If coursebooks' values are accepted in English language teaching, it has to be with the qualification that they have acceptable level of quality, usefulness, and appropriateness for the context and people with whom they are being used. Coursebook evaluation and material selection is not an easy job. Effective evaluation of teaching materials is a very significant professional activity for all EFL/ESL teachers. Low (1989) stated that "designing appropriate material is not a science; it is a strange mixture of imagination, insight and analytical reasoning, and this fact must be recognized when materials are assessed" (p. 153).

Several scholars proposed various definitions and interpretations for coursebook evaluation. Coursebook evaluation typically functions as a sort of educational judgment. Richards, Platt, and Weber (1985) defined evaluation as "the systematic gathering of information for purposes of making decisions" (p. 98). Hutchinson and Waters (1987, p. 41) considered evaluation as "a matter of judging the fitness of something for a particular purpose." From Tomlinson's (1998) point of view, evaluation is the systematic judgment of the value of materials in relation to the purposes of the materials and the learners who are using them.

Coursebook evaluation is of great significance as it manages to a better understanding of the nature of a specific teaching/learning situation. In addition, it is of vital importance in education and for teachers as it gives them precious information for the future going of classroom practice, for the course planning, and for the management of learning tasks and students. Finally, evaluation is necessary for the use of instructional materials such as textbooks.

The most common method of conducting a coursebook evaluation is making use of an appropriate checklist that is developed by well-known scholars. While the subject of coursebook evaluation has not been extensively investigated, several authors have offered methods of assisting teachers to be more accurate in their evaluation by demonstrating evaluation checklists based on criteria which can be used by teachers and learners in various situations. Soori, Kafipour, and Soury (2011) defined checklist as an instrument which provides the evaluator with a list of features of successful teaching/learning materials.

Several scholars have conducted a detailed investigation of a textbook's language content that has managed to the production of large amounts of evaluation checklists. One of these checklists is Cunningsworth's (1984) checklist in which he touches upon the significance of relating coursebooks to course goals and the learners' needs and processes. Another one is Sheldon's (1988) checklist which includes a large variety of components and tries to evaluate all aspects of content such as graphics and physical characteristics to authenticity and flexibility.

In spite of Sheldon's (1988) suggestion that no list of criteria can really be used in all ESL/EFL settings without modification, most of these checklists include similar parts which can be applied as useful starting points for ELT teachers in various situations. Several scholars in the field of coursebook design like Sheldon (1988), Brown (1995), and Cunningsworth (1995) all assented that evaluation checklists ought to have some criteria related to the physical features of coursebook like layout, organizational, and logistical features as well. Other significant criteria which should be included are the criteria to evaluate a coursebook's methodology, objectives, approaches and the extent to which particular materials are not only teachable, but also are appropriate for both teacher's approach and organization's curriculum. In addition, criteria have to analyze the particular language functions, grammar, and skills which are covered by a specific coursebook and the relevance of linguistic elements to the socio-cultural context. Finally, coursebook evaluations have to contain criteria which are related to presentation of culture and gender as well as the degree to which the linguistic items, subjects, content, and topics fit the learner's personalities, backgrounds, needs, and interests as well as those of the teacher and/or institution.

A review of the literature indicates that most evaluation checklists have common characteristics. For example, Skierso's (1991) checklist contains features pertaining to bibliographical data, aims and goals, subject matter, vocabulary and structures, exercises and activities, and layout and physical makeup. These characteristics are mostly consistent with those in Cunningsworth's (1995) checklist which considers aims and approaches, design and organization, language content, skills, topic, methodology, and practical considerations. Even though the topic of the parts in the two checklists seem different, an investigation of the items will display that they are approximately similar. For instance, Skierso (1991) considers the cost-effectiveness of the coursebook in the section named 'bibliographical data', while Cunningsworth (1995) refers to it in the 'practical consideration' section. Daoud and Celce-Murcia (1979) proposed a checklist for coursebook evaluation which includes five main parts: subject matter, vocabulary and structures, exercises, illustrations, and physical make-up. Every part consists of detailed strategies that can be used in assessing and analyzing every coursebook.

The checklist used in the present study was a coursebook evaluation checklist which was primarily designed by Cunningsworth (1995) and specifically modified for this study. Cunningsworth (1995) stated that since "different criteria will apply in different circumstances" (p. 2), teachers and researchers ought to identify their own priorities and develop their own checklists. The checklist used in this study consists of fifty three criteria in fourteen sections; content, grammar, vocabulary, phonology, language skills, methodology, study skills, visuals, practice and testing, 
supplementary material, objectives, content selection, gradation, and culture. Moreover, the checklist has a four-point multiple-choice Likert scale format.

\section{Method}

\subsection{Participants}

The participants of this study were selected from various language institutes of Gilan and Mazandaran provinces in which Top Notch coursebook was taught. Three institutes were selected randomly. One hundred students and 20 teachers participated in this study. Sixty four of the students and nine of the teachers were male and 36 of the students and 11 of the teachers were female. The range of teachers' experience of teaching the coursebook was between 2-4 years and the range of students' experience of studying the coursebook was between 1-3 years.

\subsection{Instruments}

The instruments employed in this study are students' and teachers' checklists modified from Cunningsworth (1995).

\subsubsection{Checklist}

The checklist employed in the present study was developed mainly from Cunningsworth's (1995) checklist after tailoring it to meet the objectives of this study. Some of the items of the questionnaire were modified and some were removed from the questionnaire since they did not suit Iran's context. These modifications were made based on the interviews that the researcher had with four TEFL experts. Cunningsworth (1995) proposed that as "different criteria will apply in different circumstances" (p. 2), teachers or researchers ought to specify their own priorities and prepare their own checklists. Sheldon (1988) states "any culturally restricted, global list of criteria can never really apply in most local environments, without considerable modification" (p. 242). Therefore, the items of the cultural section of the questionnaire were taken from Shatery and Azargoon's (2012) nativized checklist.

The checklist used in the study includes 53 criteria in 14 categories: content, grammar, vocabulary, phonology, language skills, methodology, study skills, visuals, practice and testing, supplementary material, objectives, content selection, gradation, and culture. It was used to indicate participants' opinions regarding the four coursebooks used in the study. A four-point multiple-choice Likert scale format, ranging 1-4, was used to show participants' level of agreement with a list of statements. Each statement was weighted equally (1 point for each strongly disagree, 2 points for each disagree, 3 points for each agree, and 4 points for each strongly agree). All scores were converted to percentile rankings $(0-100 \%)$.

Students and teachers completed the same version of checklist, to allow for comparison across groups, although the teachers' version included some additional items. One of the benefits of employing a single questionnaire was avoiding linguistic and cultural biases, and also achieving results which were as precise as possible. While both questionnaires included nine common categories (statements 1-30) - content, grammar, vocabulary, phonology, language skills, methodology, study skills, visuals, and practice and testing- the teachers' questionnaire had five additional categories: supplementary material, objectives, content selection, gradation, and culture (statements 31-53). Both questionnaires had an open-ended section where participants were given the opportunity to write their own comments or suggestions regarding the coursebook. Finally, the researcher reviewed the coursebook thoroughly to provide a descriptive analysis of the 14 categories.

In addition to English statements, students' checklist was accompanied by Persian translation of the statements in order to remove any ambiguities for students in understanding the statements of the questionnaire. In order to ensure the validity of the checklist's translation, the researcher asked a translation expert to translate the questionnaire into Persian. The Persian translations were translated into English by three experts. The comparison of these three translated checklists with the original one showed no considerable difference; therefore, it was concluded that the Persian translation of the checklist was valid.

\subsubsection{Pilot study}

In order to estimate how reliable the use of the checklist is, the researcher administered the checklist to the pilot group of 30 students and 30 teachers. Cronbach's Alpha was used for the computation of the internal consistency of the checklist. The reliability index for the present study's checklist was found to be 0.94 , for students' questionnaire and 0.86 for teachers' questionnaire, both are considered high reliabilities.

To ensure the content and face validity of the checklist, the comments of five experts were sought. Each strongly confirmed the appropriateness of the checklist in regard to the general objective of evaluating coursebooks.

It is worth mentioning that the researcher took advantage of the students' and the teachers' comments and suggestions about the questionnaire and applied some slight modifications in the final version.

\subsection{Procedure}

This study aimed at evaluating the most frequently used foreign coursebook in Iran, namely Top Notch. The data collection took place in three institutes of Gilan and Mazandaran provinces. The coursebook, evaluated based on the evaluation checklist, was the intermediate level of Top Notch. The textbook was evaluated by both students and teachers based on administering written questionnaires. The researcher requested institutes' supervisors for permission to administer the research instruments in the selected classes in collaboration with class teachers. The questionnaires were administered and collected in one session. The researcher himself attended administration sessions in order to clarify any probable ambiguities for students and teachers. Before administering the questionnaire, the project was 
explained to the participants in the study in order to guarantee their cooperation. All the participants were given an oral description of objectives and procedures of the questionnaire. They were also assured that the results would be kept confidential. They had ample amount of time to go over the questionnaire items and answer them.

In order to empower the gathered data, 25 percent of the teachers and 10 percent of the students attended to an interview session. The researchers' final insights and overall evaluation of the coursebooks were made in section four after analyzing the gathered data. In this section, the weakness and strengths of the coursebook were discussed. Once the data were collected, appropriate statistical tests were used to find out the significance of the results.

\section{Results}

In this section, all the administered questionnaires from both teachers' and students' perspectives were analyzed and their reports were presented.

\subsection{Analysis of the Questionnaires}

Table 1. Result of the descriptive statistics, percentage and Chi-square of the teachers' responses related to content

\begin{tabular}{|c|c|c|c|c|c|c|c|c|c|c|}
\hline & & & & & Perce & tage & & & & \\
\hline & & $\mathrm{N}$ & Mean & Deviation & $\begin{array}{l}\text { S. } \\
\text { Agr. }\end{array}$ & Agr. & $\begin{array}{l}\text { D.A } \\
\text { gr }\end{array}$ & $\begin{array}{l}\text { S. D. } \\
\text { Agr }\end{array}$ & $\begin{array}{l}\text { squar } \\
\text { e }\end{array}$ & $\begin{array}{l}\text { If Asymp } \\
\text {. Sig. }\end{array}$ \\
\hline 1. & The selected topics are familiar to the students. & 20 & 3.15 & .67 & 25 & 70 & 0 & 5 & 13.30 & 2.00 \\
\hline 2. & The selected topics enhance learners' motivation. & 20 & 3.05 & .69 & 25 & 55 & 20 & 0 & 4.30 & 2.116 \\
\hline 3. & $\begin{array}{l}\text { The } \mathrm{CB} \text { contains adequate self-check progress } \\
\text { report. }\end{array}$ & 20 & 2.85 & .74 & 15 & 60 & 20 & 5 & 14.00 & 3.00 \\
\hline 4. & $\begin{array}{l}\text { Texts and dialogues include new vocabulary and } \\
\text { grammatical structures. }\end{array}$ & 20 & 3.20 & .83 & 40 & 45 & 10 & 5 & 10.00 & 3.019 \\
\hline 5. & $\begin{array}{l}\text { Language items (e.g. vocabulary, etc) are } \\
\text { presented in context to make meaning clear. }\end{array}$ & 20 & 2.90 & .97 & 30 & 40 & 20 & 10 & 4.00 & 3.26 \\
\hline 6. & $\begin{array}{l}\text { Pedagogic texts and dialogues include a variety of } \\
\text { interesting subjects. }\end{array}$ & 20 & 2.75 & .85 & 20 & 40 & 35 & 5 & 6.00 & 3.11 \\
\hline
\end{tabular}

Note. S. Agr. $=$ Strongly Agree; Agr. $=$ Agree; D. Agr. $=$ Disagree; S. D. Agr. $=$ Strongly

As it is indicated in table 1, in item one, $25 \%$ of the teachers strongly agreed and $70 \%$ of them agreed that the selected topics are familiar to the students. Moreover, $5 \%$ of the teachers strongly disagreed with the item $(\mathrm{M}=3.15, \mathrm{SD}=.67$; SUM. of S. Agr. \&Agr. =95\%). In addition, there is a significant difference between the number of teachers who agreed and the ones who strongly agreed and strongly disagreed with this item, $c^{2}(1, N=20)=13.30, p<.05$.

In the second item, $25 \%$ of the teachers strongly agreed and 55\% of them agreed that the selected topics enhance learners' motivation. Moreover, $20 \%$ of the teachers had the opposite idea and disagreed with the item $(\mathrm{M}=3.05$, $\mathrm{SD}=.69$; SUM. of S. Agr. \&Agr. $=80 \%$ ). In addition, there is no significant difference between the number of teachers who agreed and the ones who strongly agreed and disagreed with this item, $\mathrm{c}^{2}(2, \mathrm{~N}=20)=4.30, \mathrm{p}>.05$.

The next item considers whether Top Notch coursebook contains adequate self-check progress report or not. The results show that $15 \%$ of the teachers strongly agreed and $60 \%$ of them agreed that the coursebook contains adequate selfcheck progress report. In addition, $20 \%$ of the teachers disagreed and $5 \%$ of them strongly disagreed with this item (M $=2.85, \mathrm{SD}=.74$; SUM. of S. Agr. \&Agr. $=75 \%$ ). Moreover, there is a significant difference between the number of teachers who agreed and the ones who strongly agreed and disagreed with this item, $c^{2}(2, N=20)=14.00, p<.05$.

The findings in item 4 display that $40 \%$ of the teachers strongly agreed and $45 \%$ of them agreed that texts and dialogues include new vocabulary and grammatical structures. Moreover, $10 \%$ of the teachers disagreed and $5 \%$ of them strongly disagreed with the item $(\mathrm{M}=3.20, \mathrm{SD}=.83$; SUM. of $\mathrm{S}$. Agr. \&Agr. $=85 \%)$. In addition, there is a significant difference between the number of teachers who agreed and the ones who strongly agreed, disagreed and strongly disagreed with this item, $\mathrm{c}^{2}(1, \mathrm{~N}=20)=10.00, \mathrm{p}<.05$.

The fifth item considers if language items (e.g. vocabulary, etc) are presented in context to make meaning clear. The results show that $30 \%$ of the teachers strongly agreed and $40 \%$ of them agreed that the language items (e.g. vocabulary, 
etc) are presented in context to make meaning clear. In addition, $20 \%$ of the teachers disagreed and $10 \%$ of them strongly disagreed with this item $(\mathrm{M}=2.90, \mathrm{SD}=.97$; $\mathrm{SUM}$. of $\mathrm{S}$. Agr. \&Agr. $=70 \%)$. Moreover, there is no significant difference between the number of teachers who agreed and the ones who strongly agreed, disagreed, and strongly disagreed with this item, $\mathrm{c}^{2}(2, \mathrm{~N}=20)=4.00, \mathrm{p}>.05$.

In the last item of this category, $20 \%$ of the teachers strongly agreed and $40 \%$ of them agreed that pedagogic texts and dialogues include a variety of interesting subjects. In addition, 35\% of the teachers disagreed and 5\% of them strongly disagreed with this item $(\mathrm{M}=2.75, \mathrm{SD}=.85$; SUM. of $\mathrm{S}$. Agr. \&Agr. $=60 \%)$. Moreover, there is no significant difference between the number of teachers who agreed and the ones who strongly agreed, disagreed, and strongly disagreed with this item, $\mathrm{c}^{2}(3, \mathrm{~N}=20)=6.00, \mathrm{p}>.05$.

Table 2. Result of the descriptive statistics, percentage and Chi-square of the students' responses related to content

\begin{tabular}{|c|c|c|c|c|c|c|c|c|c|c|}
\hline & & \multirow[b]{2}{*}{$\mathrm{N}$} & \multirow[b]{2}{*}{ Mean } & \multirow{2}{*}{$\begin{array}{l}\text { Std. } \\
\text { Deviation }\end{array}$} & \multicolumn{4}{|c|}{ Percentage } & \multirow{2}{*}{$\begin{array}{l}\text { Chi- } \\
\text { squar } \\
\mathrm{e}\end{array}$} & \multirow{2}{*}{$\begin{array}{l}\text { df Asymp } \\
\text {. Sig. }\end{array}$} \\
\hline & & & & & $\begin{array}{l}\text { S. } \\
\text { Agr. }\end{array}$ & Agr. & $\begin{array}{l}\text { D.A } \\
\text { gr }\end{array}$ & $\begin{array}{l}\text { S. D. } \\
\text { Agr }\end{array}$ & & \\
\hline 1. & The selected topics are familiar to the students. & 100 & 3.10 & .58 & 22 & 66 & 12 & 0 & 49.52 & 2.00 \\
\hline 2. & The selected topics enhance learners' motivation. & 100 & 3.06 & .78 & 27 & 58 & 9 & 6 & 68.40 & 3.00 \\
\hline 3. & $\begin{array}{l}\text { The } \mathrm{CB} \text { contains adequate self-check progress } \\
\text { report. }\end{array}$ & 100 & 2.94 & .72 & 21 & 54 & 23 & 2 & 55.60 & 3.00 \\
\hline 4. & $\begin{array}{l}\text { Texts and dialogues include new vocabulary and } \\
\text { grammatical structures. }\end{array}$ & 100 & 3.23 & .63 & 34 & 55 & 11 & 0 & 29.06 & 2.00 \\
\hline 5. & $\begin{array}{l}\text { Language items (e.g. vocabulary, etc) are } \\
\text { presented in context to make meaning clear. }\end{array}$ & 100 & 3.23 & .75 & 39 & 48 & 10 & 3 & 57.36 & 3.00 \\
\hline 6. & $\begin{array}{l}\text { Pedagogic texts and dialogues include a variety of } \\
\text { interesting subjects. }\end{array}$ & 100 & 2.91 & .77 & 21 & 54 & 20 & 5 & 51.28 & 3.00 \\
\hline
\end{tabular}

As it is indicated in table 2, in the first item, $22 \%$ of the students strongly agreed and $66 \%$ of them agreed that the selected topics are familiar to the students. Moreover, $12 \%$ of the students had the opposite idea and disagreed with the item $(\mathrm{M}=3.10, \mathrm{SD}=.58$; SUM. of S. Agr. \&Agr. $=88 \%)$. In addition, there is a significant difference between the number of students who agreed and the ones who strongly agreed and disagreed with this item, $\mathrm{c}^{2}(2, \mathrm{~N}=100)=49.52$, $\mathrm{p}<.05$.

In the second item, $27 \%$ of the students strongly agreed and 58\% of them agreed that the selected topics enhance learners' motivation. Moreover, $9 \%$ of the students disagreed and $6 \%$ of them strongly disagreed with the item $(\mathrm{M}=$ $3.06, \mathrm{SD}=.78$; SUM. of S. Agr. \&Agr. $=85 \%$ ). In addition, there is a significant difference between the number of students who agreed and the ones who strongly agreed, disagreed and strongly disagreed with this item, $\mathrm{c}^{2}(3, \mathrm{~N}=$ $100)=68.40, \mathrm{p}<.05$.

The next item considers whether Top Notch coursebook contains adequate self-check progress report or not. The results show that $21 \%$ of the students strongly agreed and $54 \%$ of them agreed that the coursebook contains adequate selfcheck progress report. In addition, $23 \%$ of the students disagreed and $2 \%$ of them strongly disagreed with this item (M $=2.94, \mathrm{SD}=.72$; SUM. of S. Agr. \&Agr. $=75 \%$ ). Moreover, there is a significant difference between the number of students who agreed and the ones who strongly agreed, disagreed and strongly disagreed with this item, $\mathrm{c}^{2}(3, \mathrm{~N}=$ $100)=55.60, \mathrm{p}<.05$.

The findings in item 4 display that 34\% of the students strongly agreed and 55\% of them agreed that texts and dialogues include new vocabulary and grammatical structures. In addition, $11 \%$ of the students disagreed with this item $(\mathrm{M}=3.23, \mathrm{SD}=.63$; SUM. of S. Agr. \&Agr. $=89 \%)$. However, there is a significant difference between the number of students who agreed and the ones who strongly agreed and disagreed with this item, $\mathrm{c}^{2}(2, \mathrm{~N}=100)=29.06, \mathrm{p}<.05$.

The fifth item considers if language items (e.g. vocabulary, etc) are presented in context to make meaning clear. The results show that $39 \%$ of the students strongly agreed and $48 \%$ of them agreed that the language items (e.g. vocabulary, etc) are presented in context to make meaning clear. In addition, $10 \%$ of the students disagreed and $3 \%$ of them strongly disagreed with this item $(\mathrm{M}=3.10, \mathrm{SD}=.64$; SUM. of $\mathrm{S}$. Agr. \&Agr. $=87 \%)$. Moreover, there is a significant difference between the number of students who agreed and the ones who strongly agreed, disagreed and strongly disagreed with this item, $\mathrm{c}^{2}(3, \mathrm{~N}=100)=57.36, \mathrm{p}<.05$.

In the last item of this category, $21 \%$ of the students strongly agreed and $54 \%$ of them agreed that the pedagogic texts and dialogues include a variety of interesting subjects. In addition, $20 \%$ of the students disagreed and $5 \%$ of them 
strongly disagreed with this item $(\mathrm{M}=2.91, \mathrm{SD}=.77$; SUM. of $\mathrm{S}$. Agr. \&Agr. $=75 \%)$. Moreover, there is a significant difference between the number of students who agreed and the ones who strongly agreed,disagreed and strongly disagreed with this item, $\mathrm{c}^{2}(3, \mathrm{~N}=100)=51.28, \mathrm{p}<.05$.

Table 3. Result of the descriptive statistics, percentage and Chi-square of the teachers' responses related to grammar

\begin{tabular}{|c|c|c|c|c|c|c|c|c|c|}
\hline & \multirow[b]{2}{*}{$\mathrm{N}$} & \multirow[b]{2}{*}{ Mean } & \multirow{2}{*}{$\begin{array}{l}\text { Std. } \\
\text { Deviation }\end{array}$} & \multicolumn{4}{|c|}{ Percentage } & \multirow{2}{*}{$\begin{array}{l}\text { Chi- } \\
\text { squar } \\
\text { e }\end{array}$} & \multirow{2}{*}{$\begin{array}{l}\text { df Asymp } \\
\text {. Sig. }\end{array}$} \\
\hline & & & & $\begin{array}{l}\text { S. } \\
\text { Agr. }\end{array}$ & Agr. & $\begin{array}{l}\text { D.A } \\
\text { gr }\end{array}$ & $\begin{array}{l}\text { S. D. } \\
\text { Agr }\end{array}$ & & \\
\hline $\begin{array}{l}\text { 7. The paradigm used to introduce grammatical rules } \\
\text { is clear and simple. }\end{array}$ & 19 & 3.2 & .71 & 36.8 & 47.4 & 15.8 & 0 & 2.94 & 2.23 \\
\hline 8. Grammar items suit students' language needs. & 19 & 3.26 & .80 & 42.1 & 47.4 & 5.3 & 5.3 & 11.94 & 3.01 \\
\hline 9. There is a balance between form and use. & 20 & 2.95 & .94 & 30 & 45 & 15 & 10 & 6.00 & 3.11 \\
\hline $\begin{array}{l}\text { 10. Sentences and examples contain words that are } \\
\text { known by learners. }\end{array}$ & 20 & 3.00 & .79 & 25 & 55 & 15 & 5 & 11.20 & 3.01 \\
\hline
\end{tabular}

As displayed in table 3, in item 7,36.8\% of the teachers strongly agreed and $47.4 \%$ of them agreed that the paradigm used to introduce grammatical rules is clear and simple. In addition, $15.8 \%$ of the teachers disagreed with the item $(\mathrm{M}=$ 3.20, SD=.71; SUM. of S. Agr. \&Agr. $=84.2 \%$ ). Moreover, there is no significant difference between the number of teachers who agreed and the ones who strongly agreed and disagreed with this item, $\mathrm{c}^{2}(2, \mathrm{~N}=19)=2.94, \mathrm{p}>.05$.

The eighth item considers whether grammar items suit students' language needs. The results show that $42.1 \%$ of the teachers strongly agreed and $47.3 \%$ of them agreed that grammar items suit students' language needs. Moreover, 5.3\% of the teachers disagreed and $5.3 \%$ of them strongly disagreed with this item $(\mathrm{M}=3.26, \mathrm{SD}=.80$; SUM. of $\mathrm{S}$. Agr. \&Agr. $=89.4 \%$ ). In addition, there is a significant difference between the number of teachers who agreed and the ones who strongly agreed and disagreed with this item, $\mathrm{c}^{2}(2, \mathrm{~N}=19)=11.94, \mathrm{p}<.05$.

In item 9,30\% of the teachers strongly agreed and 45\% of them agreed that there is a balance between form and use. In addition, $15 \%$ of the teachers disagreed and $10 \%$ of them strongly disagreed with this item $(\mathrm{M}=2.95, \mathrm{SD}=.94 ; \mathrm{SUM}$. of S. Agr. \&Agr. $=75 \%$ ). Moreover, there is no significant difference between the number of teachers who agreed and the ones who strongly agreed, disagreed, and strongly disagreed with this item, $\mathrm{c}^{2}(3, \mathrm{~N}=20)=6.00, \mathrm{p} \geqslant .05$.

Item 10 considers if sentences and examples contain words that are known by learners. The findings display that $25 \%$ of the teachers strongly agreed and 55\% of them agreed that sentences and examples contain words that are known by learners. In addition, $15 \%$ of the teachers disagreed and $5 \%$ of them strongly disagreed with this item $(\mathrm{M}=3.00$, $\mathrm{SD}=.79$; SUM. of S. Agr. \&Agr. $=80 \%$ ). Moreover, there is a significant difference between the number of teachers who agreed and the ones who strongly agreed,disagreed and strongly disagreed with this item, $\mathrm{c}^{2}(2, \mathrm{~N}=20)=11.20$, $\mathrm{p}<.05$.

Table 4. Result of the descriptive statistics, percentage and Chi-square of the students' responses related to grammar

\begin{tabular}{|c|c|c|c|c|c|c|c|c|c|c|}
\hline & \multirow[b]{2}{*}{$\mathrm{N}$} & \multirow[b]{2}{*}{ Mean } & \multirow{2}{*}{$\begin{array}{l}\text { Std. } \\
\text { Deviation }\end{array}$} & \multicolumn{4}{|c|}{ Percentage } & \multirow{2}{*}{$\begin{array}{l}\text { Chi- } \\
\text { squar } \\
\text { e }\end{array}$} & \multirow{2}{*}{ df } & \multirow{2}{*}{$\begin{array}{l}\text { Asymp } \\
\text {. Sig. }\end{array}$} \\
\hline & & & & $\begin{array}{l}\text { S. } \\
\text { Agr. }\end{array}$ & Agr. & $\begin{array}{l}\text { D.A } \\
\text { gr }\end{array}$ & $\begin{array}{l}\text { S. D. } \\
\text { Agr }\end{array}$ & & & \\
\hline $\begin{array}{l}\text { 7. The paradigm used to introduce grammatical rules } \\
\text { is clear and simple. }\end{array}$ & 100 & 3.15 & .79 & 36 & 47 & 13 & 4 & 47.60 & 3 & .00 \\
\hline 8. Grammar items suit students' language needs. & 100 & 3.05 & .77 & 28 & 53 & 15 & 4 & 53.36 & 3 & .00 \\
\hline 9. There is a balance between form and use. & 100 & 2.92 & .72 & 21 & 51 & 27 & 1 & 50.88 & 3 & .00 \\
\hline $\begin{array}{l}\text { 10. Sentences and examples contain words that are } \\
\text { known by learners. }\end{array}$ & 100 & 3.14 & .82 & 36 & 47 & 12 & 5 & 46.96 & 3 & .00 \\
\hline
\end{tabular}

As indicated in table 4, in item 7, 36\% of the students strongly agreed and 47\% of them agreed that the paradigm used to introduce grammatical rules is clear and simple. In addition, 13\% of the students disagreed and $4 \%$ of them strongly disagreed with this item $(\mathrm{M}=3.15, \mathrm{SD}=.79$; SUM. of $\mathrm{S}$. Agr. \&Agr. $=83 \%)$. Moreover, there is a significant 
difference between the number of students who agreed and the ones who strongly agreed, disagreed and strongly disagreed with this item, $\mathrm{c}^{2}(3, \mathrm{~N}=100)=47.60, \mathrm{p}<.05$.

Item 8 considers if grammar items suit students' language needs. The results show that $28 \%$ of the students strongly agreed and $53 \%$ of them agreed that grammar items suit students' language needs. In addition, $15 \%$ of the students disagreed and $4 \%$ of them strongly disagreed with this item $(\mathrm{M}=3.05, \mathrm{SD}=.77$; SUM. of $\mathrm{S}$. Agr. \&Agr. $=81 \%)$. Moreover, there is a significant difference between the number of students who agreed and the ones who strongly agreed, disagreed and strongly disagreed with this item, $\mathrm{c}^{2}(3, \mathrm{~N}=100)=53.36, \mathrm{p}<.05$.

In the ninth item, $21 \%$ of the students strongly agreed and $51 \%$ of them agreed that there is a balance between form and use. In addition, $27 \%$ of the students disagreed and $1 \%$ of them strongly disagreed with this item $(\mathrm{M}=2.92, \mathrm{SD}=.72$; SUM. of S. Agr. \&Agr. $=72 \%$ ). Moreover, there is a significant difference between the number of students who agreed and the ones who strongly agreed, disagreed and strongly disagreed with this item, $\mathrm{c}^{2}(3, \mathrm{~N}=100)=50.88, \mathrm{p}<.05$.

Item 10 considers whether sentences and examples contain words that are known by learners or not. The findings indicate that $36 \%$ of the students strongly agreed and $47 \%$ of them agreed that sentences and examples contain words that are known by learners. In addition, $12 \%$ of the students disagreed and $5 \%$ of them strongly disagreed with this item $(\mathrm{M}=3.14, \mathrm{SD}=.82$; SUM. of S. Agr. \&Agr. $=83 \%)$. Moreover, there is a significant difference between the number of students who agreed and the ones who strongly agreed, disagreed and strongly disagreed with this item, $\mathrm{c}^{2}$ $(3, \mathrm{~N}=100)=46.96, \mathrm{p}<.05$.

Table 5. Result of the descriptive statistics, percentage and Chi-square of the teachers' responses related to vocabulary

\begin{tabular}{|c|c|c|c|c|c|c|c|c|c|}
\hline & \multirow[b]{2}{*}{$\mathrm{N}$} & \multirow[b]{2}{*}{ Mean } & \multirow{2}{*}{$\begin{array}{l}\text { Std. } \\
\text { Deviation }\end{array}$} & \multicolumn{4}{|c|}{ Percentage } & \multirow{2}{*}{$\begin{array}{l}\text { Chi- } \\
\text { squar } \\
\text { e }\end{array}$} & \multirow{2}{*}{ df $\begin{array}{l}\text { Asymp } \\
\text {. Sig. }\end{array}$} \\
\hline & & & & $\begin{array}{l}\text { S. } \\
\text { Agr. }\end{array}$ & Agr. & $\begin{array}{l}\text { D.A } \\
\text { gr }\end{array}$ & $\begin{array}{l}\text { S. D. } \\
\text { Agr }\end{array}$ & & \\
\hline 11. New lexical items appear in the following units. & 20 & 2.95 & .76 & 20 & 60 & 15 & 5 & 14.00 & 3.00 \\
\hline $\begin{array}{l}\text { 12. The exercises for vocabulary are rich and } \\
\text { adequate. }\end{array}$ & 20 & 3.00 & .79 & 30 & 40 & 30 & 0 & .40 & 2.82 \\
\hline
\end{tabular}

Table 5 shows that in item 11, 20\% of the teachers strongly agreed and $60 \%$ of them agreed that new lexical items appear in the following units. In addition, $15 \%$ of the teachers disagreed and $5 \%$ of them strongly disagreed with the item $(\mathrm{M}=2.95, \mathrm{SD}=.76$; $\mathrm{SUM}$. of $\mathrm{S}$. Agr. \&Agr. $=80 \%)$. Moreover, there is a significant difference between the number of teachers who agreed and the ones who strongly agreed, disagreed, and strongly disagreed with this item, $\mathrm{c}^{2}$ $(3, \mathrm{~N}=20)=14.00, \mathrm{p}<.05$.

Twelfth item considers whether the exercises for vocabulary are rich and adequate or not. The results display that $30 \%$ of the teachers strongly agreed and $40 \%$ of them agreed that the exercises for vocabulary are rich and adequate. In addition, $30 \%$ of the teachers disagreed with the item $(\mathrm{M}=3.00, \mathrm{SD}=.79$; SUM. of $\mathrm{S}$. Agr. \&Agr. $=70 \%)$. Moreover, there is no significant difference between the number of teachers who agreed and the ones who strongly agreed and disagreed with this item, $\mathrm{c}^{2}(2, \mathrm{~N}=20)=.40, \mathrm{p} \geqslant .05$.

Table 6. Result of the descriptive statistics, percentage and Chi-square of the students'responses related to vocabulary

\begin{tabular}{|c|c|c|c|c|c|c|c|c|}
\hline & \multirow[b]{2}{*}{$\mathrm{N}$} & \multirow[b]{2}{*}{ Mean } & \multirow{2}{*}{$\begin{array}{l}\text { Std. } \\
\text { Deviation }\end{array}$} & \multicolumn{4}{|c|}{ Percentage } & \multirow{2}{*}{$\begin{array}{l}\text { Chi- } \\
\text { squar df Asymp } \\
\text { e }\end{array}$} \\
\hline & & & & $\begin{array}{l}\text { S. } \\
\text { Agr. }\end{array}$ & Agr. & $\begin{array}{l}\text { D.A } \\
\text { gr }\end{array}$ & $\begin{array}{l}\text { S. D. } \\
\text { Agr }\end{array}$ & \\
\hline 11. New lexical items appear in the following units. & 100 & 2.85 & .82 & 20 & 52 & 21 & 7 & $\begin{array}{lll}43.76 & 3 & 00\end{array}$ \\
\hline $\begin{array}{l}\text { 12. The exercises for vocabulary are rich and } \\
\text { adequate. }\end{array}$ & 100 & 2.85 & .83 & 21 & 50 & 22 & 7 & $38.96^{3} .00$ \\
\hline
\end{tabular}

Table 6 demonstrates that in item 11, 20\% of the students strongly agreed and 52\% of them agreed that new lexical items appear in the following units. In addition, $21 \%$ of the students disagreed and $7 \%$ of them strongly disagreed with this item $(\mathrm{M}=2.85, \mathrm{SD}=.82$; SUM. of S. Agr. \&Agr. $=72 \%)$. Moreover, there is a significant difference between the number of students who agreed and the ones who strongly agreed, disagreed and strongly disagreed with this item, $\mathrm{c}^{2}$ $(3, \mathrm{~N}=100)=43.76, \mathrm{p}<.05$.

In item $12,21 \%$ of the students strongly agreed and 50\% of them agreed that the exercises for vocabulary are rich and adequate. In addition, $22 \%$ of the students disagreed and $7 \%$ of them strongly disagreed with this item $(\mathrm{M}=2.85$, $\mathrm{SD}=.83$; SUM. of S. Agr. \&Agr. = 71\%). Moreover, there is a significant difference between the number of students who agreed and the ones who strongly agreed, disagreed and strongly disagreed with this item, $\mathrm{c}^{2}(3, \mathrm{~N}=100)=$ $38.96, \mathrm{p}<.05$. 
Table 7. Result of the descriptive statistics, percentage and Chi-square of the teachers'responses related to phonology

\begin{tabular}{|c|c|c|c|c|c|c|c|c|c|}
\hline & \multirow[b]{2}{*}{$\mathrm{N}$} & \multirow[b]{2}{*}{ Mean } & \multirow{2}{*}{$\begin{array}{l}\text { Std. } \\
\text { Deviation }\end{array}$} & \multicolumn{4}{|c|}{ Percentage } & \multirow{2}{*}{\multicolumn{2}{|c|}{$\begin{array}{l}\text { Chi- } \\
\text { squar df Asymp } \\
\text { e }\end{array}$}} \\
\hline & & & & $\begin{array}{l}\text { S. } \\
\text { Agr. }\end{array}$ & Agr. & $\begin{array}{l}\text { D.A } \\
\text { gr }\end{array}$ & $\begin{array}{l}\text { S. D. } \\
\text { Agr }\end{array}$ & & \\
\hline $\begin{array}{l}\text { 13. Pronunciation is built through different types of } \\
\text { activities, such as listening, dialogue practice etc. }\end{array}$ & 20 & 2.85 & .93 & 25 & 45 & 20 & 10 & 5.20 & 3.16 \\
\hline $\begin{array}{l}\text { 14. There is an adequate amount of pronunciation } \\
\text { practice. }\end{array}$ & 20 & 2.85 & .74 & 15 & 60 & 20 & 5 & 14.00 & 3.00 \\
\hline
\end{tabular}

As shown in table 7, in item 13, 25\% of the teachers strongly agreed and $45 \%$ of them agreed that pronunciation is built through different types of activities, such as listening, dialogue practice etc. Moreover, $20 \%$ of the teachers disagreed and $10 \%$ of them strongly disagreed with this item $(\mathrm{M}=2.85, \mathrm{SD}=.93$; SUM. of $\mathrm{S}$. Agr. \&Agr. $=70 \%)$. In addition, there is no significant difference between the number of teachers who agreed and the ones who strongly agreed, disagreed and strongly disagreed with this item, $\mathrm{c}^{2}(2, \mathrm{~N}=20)=5.20, \mathrm{p}>.05$.

Item 14 considers if there is an adequate amount of pronunciation practice. The findings show that $15 \%$ of the teachers strongly agreed and $60 \%$ of them agreed that there is an adequate amount of pronunciation practice. In addition, $20 \%$ of the teachers disagreed and 5\% of them strongly disagreed with this item $(\mathrm{M}=2.85, \mathrm{SD}=.74$; SUM. of S. Agr. \&Agr. $=75 \%$ ). Moreover, there is a significant difference between the number of teachers who agreed and the ones who strongly agreed, disagreed, and strongly disagreed with this item, $\mathrm{c}^{2}(3, \mathrm{~N}=20)=14.00, \mathrm{p}<.05$.

Table 8. Result of the descriptive statistics, percentage and Chi-square of the students'responses related to phonology

\begin{tabular}{|c|c|c|c|c|c|c|c|c|}
\hline & \multirow[b]{2}{*}{$\mathrm{N}$} & \multirow[b]{2}{*}{ Mean } & \multirow{2}{*}{$\begin{array}{l}\text { Std. } \\
\text { Deviation }\end{array}$} & \multicolumn{4}{|c|}{ Percentage } & \multirow{2}{*}{$\begin{array}{l}\text { Chi- } \\
\text { squar df Asymp } \\
\text { e }\end{array}$} \\
\hline & & & & $\begin{array}{l}\text { S. } \\
\text { Agr. }\end{array}$ & Agr. & $\begin{array}{l}\text { D.A } \\
\text { gr }\end{array}$ & $\begin{array}{l}\text { S. D. } \\
\text { Agr }\end{array}$ & \\
\hline $\begin{array}{l}\text { 13. Pronunciation is built through different types of } \\
\text { activities, such as listening, dialogue practice etc. }\end{array}$ & 100 & 3.26 & .64 & 37 & 52 & 11 & 0 & $25.82 \quad 2 \quad .00$ \\
\hline $\begin{array}{l}\text { 14. There is an adequate amount of pronunciation } \\
\text { practice. }\end{array}$ & 100 & 2.74 & .90 & 20 & 45 & 24 & 11 & $24.88 \quad 3 \quad .00$ \\
\hline
\end{tabular}

As it is shown in table 8 , in item $13,37 \%$ of the students strongly agreed and $52 \%$ of them agreed that pronunciation is built through different types of activities, such as listening, dialogue practice etc. Moreover, $11 \%$ of the students had the opposite idea and disagreed with the item $(\mathrm{M}=3.26, \mathrm{SD}=.64$; SUM. of S. Agr. \&Agr. $=89 \%)$. In addition, there is a significant difference between the number of students who agreed and the ones who strongly agreed and disagreed with this item, $\mathrm{c}^{2}(2, \mathrm{~N}=100)=25.82, \mathrm{p}<.05$.

In item 14, 20\% of the students strongly agreed and 45\% of them agreed that there is an adequate amount of pronunciation practice. Moreover, $24 \%$ of the students disagreed and $11 \%$ of them strongly disagreed with the item (M $=2.74, \mathrm{SD}=.90$; SUM. of S. Agr. \&Agr. $=65 \%$ ). In addition, there is a significant difference between the number of students who agreed and the ones who strongly agreed, disagreed and strongly disagreed with this item, $\mathrm{c}^{2}(3, \mathrm{~N}=$ $100)=24.88, \mathrm{p}<.05$.

Table 9. Result of the descriptive statistics, percentage and Chi-square of the teachers'responses related to language skills

\begin{tabular}{|c|c|c|c|c|c|c|c|c|c|}
\hline & \multirow[b]{2}{*}{$\mathrm{N}$} & \multirow[b]{2}{*}{ Mean } & \multirow{2}{*}{$\begin{array}{l}\text { Std. } \\
\text { Deviation }\end{array}$} & \multicolumn{4}{|c|}{ Percentage } & \multirow{2}{*}{$\begin{array}{l}\text { Chi- } \\
\text { squar } \\
\text { e }\end{array}$} & \multirow{2}{*}{$\begin{array}{l}\text { df Asymp } \\
\text {. Sig. }\end{array}$} \\
\hline & & & & $\begin{array}{l}\text { S. } \\
\text { Agr. }\end{array}$ & Agr. & $\begin{array}{l}\text { D.A } \\
\text { gr }\end{array}$ & $\begin{array}{l}\text { S. D. } \\
\text { Agr }\end{array}$ & & \\
\hline $\begin{array}{l}\text { 15. All four language skills of listening, speaking, } \\
\text { reading, and writing are practiced in each unit. }\end{array}$ & 20 & 2.60 & 1.09 & 25 & 30 & 25 & 20 & .40 & 3.94 \\
\hline $\begin{array}{l}\text { 16. The CB uses authentic material at an appropriate } \\
\text { level. }\end{array}$ & 20 & 3.00 & .79 & 25 & 55 & 15 & 5 & 11.20 & 2.01 \\
\hline $\begin{array}{l}\text { 17. The } \mathrm{CB} \text { uses authentic listening material at an } \\
\text { appropriate level. }\end{array}$ & 18 & 2.78 & .73 & 16.7 & 44.4 & 38.9 & 0 & 2.33 & 2.31 \\
\hline
\end{tabular}


As it is indicated in table 9 , in the fifteenth item, $25 \%$ of the teachers strongly agreed and $30 \%$ of them agreed that all four language skills of listening, speaking, reading, and writing are practiced in each unit. Moreover, $25 \%$ of the teachers disagreed and $20 \%$ of them strongly disagreed with the item $(\mathrm{M}=2.60, \mathrm{SD}=1.09$; $\mathrm{SUM}$. of $\mathrm{S}$. Agr. \&Agr. $=55 \%$ ). In addition, there is not any significant difference between the number of teachers who agreed and the ones who strongly agreed, disagreed and strongly disagreed with this item, $\mathrm{c}^{2}(2, \mathrm{~N}=20)=2.60, \mathrm{p}>.05$.

In item 16, 25\% of the teachers strongly agreed and 55\% of them agreed that Top Notch coursebook uses authentic material at an appropriate level. Moreover, $15 \%$ of the teachers disagreed and $5 \%$ of them strongly disagreed with the item $(\mathrm{M}=3.00, \mathrm{SD}=.79$; SUM. of $\mathrm{S}$. Agr. \&Agr. $=80 \%)$. In addition, there is a significant difference between the number of teachers who agreed and the ones who strongly agreed, disagreed and strongly disagreed with this item, $\mathrm{c}^{2}$ $(2, \mathrm{~N}=20)=11.20, \mathrm{p}<.05$.

Item 17 considers if the Top Notch coursebook uses authentic listening material at an appropriate level. Data analysis shows that $16.7 \%$ of the teachers strongly agreed and $44.4 \%$ of them agreed that the coursebook uses authentic listening material at an appropriate level. Moreover, $38.9 \%$ of the teachers disagreed with this item $(\mathrm{M}=2.78, \mathrm{SD}=.73$; SUM. of S. Agr. \&Agr. =61.1\%). In addition, there is no significant difference between the number of teachers who agreed and the ones who strongly agreed and disagreed with this item, $\mathrm{c}^{2}(2, \mathrm{~N}=18)=2.33, \mathrm{p}>.05$.

Table 10. Result of the descriptive statistics, percentage and Chi-square of the students'responses related to language skills

\begin{tabular}{|c|c|c|c|c|c|c|c|c|}
\hline & \multirow[b]{2}{*}{$\mathrm{N}$} & \multirow[b]{2}{*}{ Mean } & \multirow{2}{*}{$\begin{array}{l}\text { Std. } \\
\text { Deviation }\end{array}$} & \multicolumn{4}{|c|}{ Percentage } & \multirow{2}{*}{$\begin{array}{l}\text { Chi- } \\
\text { squar df Asymp } \\
\text { e }\end{array}$} \\
\hline & & & & $\begin{array}{l}\text { S. } \\
\text { Agr. }\end{array}$ & Agr. & $\begin{array}{l}\text { D.A } \\
\text { gr }\end{array}$ & $\begin{array}{l}\text { S. D. } \\
\text { Agr }\end{array}$ & \\
\hline $\begin{array}{l}\text { 15. All four language skills of listening, speaking, } \\
\text { reading, and writing are practiced in each unit. }\end{array}$ & 100 & 3.20 & .75 & 38 & 46 & 14 & 2 & $\begin{array}{lll}50.40 & 3\end{array} .00$ \\
\hline $\begin{array}{l}\text { 16. The CB uses authentic material at an appropriate } \\
\text { level. }\end{array}$ & 100 & 2.96 & .80 & 24 & 54 & 16 & 6 & $\begin{array}{lll}51.36 & 3\end{array} .00$ \\
\hline $\begin{array}{l}\text { 17. The CB uses authentic listening material at an } \\
\text { appropriate level. }\end{array}$ & 100 & 2.90 & .72 & 17 & 60 & 19 & 4 & $\begin{array}{lll}70.64 & 3\end{array} .00$ \\
\hline
\end{tabular}

Table 10 shows that in item $15,38 \%$ of the students strongly agreed and $46 \%$ of them agreed that all four language skills of listening, speaking, reading, and writing are practiced in each unit. In addition, $14 \%$ of the students disagreed and $2 \%$ of them strongly disagreed with this item $(\mathrm{M}=3.20, \mathrm{SD}=.75$; SUM. of $\mathrm{S}$. Agr. \&Agr. $=84 \%)$. Moreover, there is a significant difference between the number of students who agreed and the ones who strongly agreed, disagreed and strongly disagreed with this item, $\mathrm{c}^{2}(3, \mathrm{~N}=100)=50.40, \mathrm{p}<.05$.

Item 16 considers whether Top Notch coursebook uses authentic material at an appropriate level or not. The findings indicate that $24 \%$ of the students strongly agreed and $54 \%$ of them agreed that the coursebook uses authentic material at an appropriate level. In addition, $16 \%$ of the students disagreed and $6 \%$ of them strongly disagreed with this item (M $=2.96, \mathrm{SD}=.80$; SUM. of S. Agr. \&Agr. $=78 \%$ ). Moreover, there is a significant difference between the number of students who agreed and the ones who strongly agreed, disagreed and strongly disagreed with this item, $\mathrm{c}^{2}(3, \mathrm{~N}=$ $100)=51.36, \mathrm{p}<.05$.

In item $17,17 \%$ of the students strongly agreed and $60 \%$ of them agreed that Top Notch coursebook uses authentic listening material at an appropriate level. In addition, $19 \%$ of the students disagreed and $4 \%$ of them strongly disagreed with this item $(\mathrm{M}=2.90, \mathrm{SD}=.72$; SUM. of $\mathrm{S}$. Agr. \&Agr. $=77 \%)$. Moreover, there is a significant difference between the number of students who agreed and the ones who strongly agreed, disagreed and strongly disagreed with this item, $\mathrm{c}^{2}(3, \mathrm{~N}=100)=70.64, \mathrm{p}<.05$.

Table 11. Result of the descriptive statistics, percentage and Chi-square of the teachers'responses related to methodology

\begin{tabular}{|c|c|c|c|c|c|c|c|c|c|}
\hline & \multirow[b]{2}{*}{$\mathrm{N}$} & \multirow[b]{2}{*}{ Mean } & \multirow{2}{*}{$\begin{array}{l}\text { Std. } \\
\text { Deviation }\end{array}$} & \multicolumn{4}{|c|}{ Percentage } & \multirow{2}{*}{$\begin{array}{l}\text { Chi- } \\
\text { squar } \\
\mathrm{e}\end{array}$} & \multirow{2}{*}{ df Asymp } \\
\hline & & & & $\begin{array}{l}\text { S. } \\
\text { Agr. }\end{array}$ & Agr. & $\begin{array}{l}\text { D.A } \\
\text { gr }\end{array}$ & $\begin{array}{l}\text { S. D. } \\
\text { Agr }\end{array}$ & & \\
\hline 18. The $\mathrm{CB}$ units are related to student needs. & 20 & 3.00 & .72 & 25 & 50 & 25 & 0 & 2.50 & 2.29 \\
\hline $\begin{array}{l}\text { 19. The } \mathrm{CB} \text { encourages inductive approach to } \\
\text { learning. }\end{array}$ & 20 & 2.85 & .74 & 15 & 60 & 20 & 5 & 14.00 & 3.00 \\
\hline 20. Accuracy is balanced with fluency. & 20 & 2.80 & .77 & 15 & 55 & 25 & 5 & 11.20 & 3.01 \\
\hline
\end{tabular}


As shown in table 11, in item 18, 25\% of the teachers strongly agreed and 50\% of them agreed that Top Notch coursebook units are related to student needs. Moreover, $25 \%$ of the teachers disagreed with this item $(\mathrm{M}=3.00$, $\mathrm{SD}=.72$; SUM. of S. Agr. \&Agr. =75\%). In addition, there is no significant difference between the number of teachers who agreed and the ones who strongly agreed and disagreed with this item, $\mathrm{c}^{2}(2, \mathrm{~N}=20)=2.50, \mathrm{p}>.05$.

Item 19 considers whether Top Notch coursebook encourages inductive approach to learning or not. The results indicate that $15 \%$ of the teachers strongly agreed and $60 \%$ of them agreed that the coursebook encourages inductive approach to learning. Moreover, $20 \%$ of the teachers disagreed and 5\% of them strongly disagreed with this item $(\mathrm{M}=2.85$, $\mathrm{SD}=.74$; SUM. of S. Agr. \&Agr. $=75 \%$ ). In addition, there is a significant difference between the number of teachers who agreed and the ones who strongly agreed, disagreed and strongly disagreed with this item, $\mathrm{c}^{2}(3, \mathrm{~N}=20)=14.00$, $\mathrm{p} \leqslant .05$.

In the last item of this category, 15\% of the teachers strongly agreed and 55\% of them agreed that accuracy is balanced with fluency. In addition, $25 \%$ of the teachers disagreed and 5\% of them strongly disagreed with this item $(\mathrm{M}=2.80$, $\mathrm{SD}=.77$; SUM. of S. Agr. \&Agr. $=70 \%$ ). Moreover, there is a significant difference between the number of teachers who agreed and the ones who strongly agreed, disagreed and strongly disagreed with this item, $\mathrm{c}^{2}(3, \mathrm{~N}=20)=11.20$, $\mathrm{p}<.05$.

Table 12. Result of the descriptive statistics, percentage and Chi-square of the students'responses related to methodology

\begin{tabular}{|c|c|c|c|c|c|c|c|c|}
\hline & \multirow[b]{2}{*}{$\mathrm{N}$} & \multirow[b]{2}{*}{ Mean } & \multirow{2}{*}{$\begin{array}{l}\text { Std. } \\
\text { Deviation }\end{array}$} & \multicolumn{4}{|c|}{ Percentage } & \multirow{2}{*}{$\begin{array}{ll}\text { Chi- } & \\
\text { squar df Asymp } \\
\text { e }\end{array}$} \\
\hline & & & & $\begin{array}{l}\text { S. } \\
\text { Agr. }\end{array}$ & Agr. & $\begin{array}{l}\text { D.A } \\
\text { gr }\end{array}$ & $\begin{array}{l}\text { S. D. } \\
\text { Agr }\end{array}$ & \\
\hline 18. The $\mathrm{CB}$ units are related to student needs. & 100 & 3.00 & .76 & 26 & 51 & 20 & 3 & $\begin{array}{lll}47.44 \quad 3 \quad .00\end{array}$ \\
\hline $\begin{array}{l}\text { 19. The } \mathrm{CB} \text { encourages inductive approach to } \\
\text { learning. }\end{array}$ & 100 & 2.91 & .68 & 15 & 65 & 16 & 4 & $\begin{array}{lll}88.88 & 3 & .00\end{array}$ \\
\hline 20. Accuracy is balanced with fluency. & 100 & 3.04 & .79 & 29 & 50 & 17 & 4 & $\begin{array}{lll}45.84 & 3 & .00\end{array}$ \\
\hline
\end{tabular}

As indicated in table 12, in item 18, 26\% of the students strongly agreed and 51\% of them agreed that the coursebook units are related to student needs. In addition, $20 \%$ of the students disagreed and $3 \%$ of them strongly disagreed with this item $(\mathrm{M}=3.00, \mathrm{SD}=.76$; SUM. of S. Agr. \&Agr. = 77\%). Moreover, there is a significant difference between the number of students who agreed and the ones who strongly agreed, disagreed and strongly disagreed with this item, $\mathrm{c}^{2}$ $(3, \mathrm{~N}=100)=47.44, \mathrm{p} \leqslant .05$.

Item 19 considers if Top Notch coursebook encourages inductive approach to learning. The findings indicate that $15 \%$ of the students strongly agreed and 65\% of them agreed that the coursebook encourages inductive approach to learning. In addition, $16 \%$ of the students disagreed and $4 \%$ of them strongly disagreed with this item $(\mathrm{M}=2.91, \mathrm{SD}=.68 ; \mathrm{SUM}$. of S. Agr. \&Agr. = 80\%). Moreover, there is a significant difference between the number of students who agreed and the ones who strongly agreed, disagreed and strongly disagreed with this item, $\mathrm{c}^{2}(3, \mathrm{~N}=100)=88.88, \mathrm{p}<.05$.

In item 20, 29\% of the students strongly agreed and 50\% of them agreed that accuracy is balanced with fluency. In addition, $17 \%$ of the students disagreed and $4 \%$ of them strongly disagreed with this item $(\mathrm{M}=3.04, \mathrm{SD}=.79$; $\mathrm{SUM}$. of S. Agr. \&Agr. =79\%). Moreover, there is a significant difference between the number of students who agreed and the ones who strongly agreed, disagreed and strongly disagreed with this item, $\mathrm{c}^{2}(3, \mathrm{~N}=100)=45.84, \mathrm{p}<.05$.

Table 13. Result of the descriptive statistics, percentage and Chi-square of the teachers'responses related to study skills

\begin{tabular}{|c|c|c|c|c|c|c|c|c|c|c|}
\hline & \multirow[b]{2}{*}{$\mathrm{N}$} & \multirow[b]{2}{*}{ Mean } & \multirow{2}{*}{$\begin{array}{l}\text { Std. } \\
\text { Deviation }\end{array}$} & \multicolumn{4}{|c|}{ Percentage } & \multirow{2}{*}{$\begin{array}{l}\text { Chi- } \\
\text { squar } \\
\mathrm{e}\end{array}$} & \multirow[b]{2}{*}{ df } & \multirow{2}{*}{$\begin{array}{l}\text { Asymp } \\
\text { Sig. }\end{array}$} \\
\hline & & & & $\begin{array}{l}\text { S. } \\
\text { Agr. }\end{array}$ & Agr. & $\begin{array}{l}\text { D.A } \\
\text { gr }\end{array}$ & $\begin{array}{l}\text { S. D. } \\
\text { Agr }\end{array}$ & & & \\
\hline $\begin{array}{l}\text { 21. The CB includes lessons that reflect on study } \\
\text { techniques such as vocabulary learning techniques }\end{array}$ & 20 & 2.75 & .91 & 20 & 45 & 25 & 10 & 5.20 & 3 & .16 \\
\hline $\begin{array}{l}\text { 22. The CB contains advice on study skills } \\
\text { development. }\end{array}$ & 20 & 2.65 & .87 & 15 & 45 & 30 & 10 & 6.00 & 3 & .11 \\
\hline $\begin{array}{l}\text { 23. Students are encouraged to take some degree of } \\
\text { responsibility for their learning. }\end{array}$ & 19 & 2.58 & .77 & 5.3 & 57.9 & 26.3 & 10.5 & 12.78 & 3 & .00 \\
\hline $\begin{array}{l}\text { 24. There are some materials for independent work in } \\
\text { each unit. }\end{array}$ & 20 & 2.85 & .93 & 25 & 45 & 20 & 10 & 5.20 & 3 & .16 \\
\hline
\end{tabular}


Table 13 indicates that in item 21, 20\% of the teachers strongly agreed and 45\% of them agreed that Top Notch coursebook includes lessons that reflect on study techniques such as vocabulary learning techniques. Moreover, $25 \%$ of the teachers disagreed and $10 \%$ of them strongly disagreed with this item $(\mathrm{M}=2.75, \mathrm{SD}=.91$; SUM. of $\mathrm{S}$. Agr. \&Agr. $=65 \%$ ). In addition, there is no significant difference between the number of teachers who agreed and the ones who strongly agreed, disagreed and strongly disagreed with this item, $\mathrm{c}^{2}(3, \mathrm{~N}=20)=5.20, \mathrm{p}>.05$.

Item 22 considers if Top Notch coursebook contains advice on study skills development. Data analysis shows that $15 \%$ of the teachers strongly agreed and 45\% of them agreed that the coursebook contains advice on study skills development. Moreover, $30 \%$ of the teachers disagreed and $10 \%$ of them strongly disagreed with this item $(\mathrm{M}=2.65$, $\mathrm{SD}=.87$; SUM. of S. Agr. \&Agr. $=60 \%$ ). In addition, there is no significant difference between the number of teachers who agreed and the ones who strongly agreed, disagreed and strongly disagreed with this item, $\mathrm{c}^{2}(3, \mathrm{~N}=20)=6.00, \mathrm{p}$ $>.05$.

In item 23, 5.3\% of the teachers strongly agreed and 57.9\% of them agreed that students are encouraged to take some degree of responsibility for their learning. Moreover, $26.3 \%$ of the teachers disagreed and $10.5 \%$ of them strongly disagreed with this item $(\mathrm{M}=2.58, \mathrm{SD}=.77$; SUM. of $\mathrm{S}$. Agr. \&Agr. $=63.2 \%)$. In addition, there is a significant difference between the number of teachers who agreed and the ones who strongly agreed, disagreed and strongly disagreed with this item, $\mathrm{c}^{2}(3, \mathrm{~N}=19)=12.78, \mathrm{p}<.05$.

In item $24,25 \%$ of the teachers strongly agreed and $45 \%$ of them agreed that there are some materials for independent work in each unit. Moreover, $20 \%$ of the teachers disagreed and $10 \%$ of them strongly disagreed with this item $(\mathrm{M}=$ 2.85, $\mathrm{SD}=.93$; SUM. of S. Agr. \&Agr. $=70 \%$ ). In addition, there is no significant difference between the number of teachers who agreed and the ones who strongly agreed, disagreed and strongly disagreed with this item, $\mathrm{c}^{2}(3, \mathrm{~N}=20)$ $=5.20, \mathrm{p}>.05$.

Table 14. Result of the descriptive statistics, percentage and Chi-square of the students'responses related to study skills

\begin{tabular}{|c|c|c|c|c|c|c|c|c|c|c|}
\hline & \multirow[b]{2}{*}{$\mathrm{N}$} & \multirow[b]{2}{*}{ Mean } & \multirow{2}{*}{$\begin{array}{l}\text { Std. } \\
\text { Deviation }\end{array}$} & \multicolumn{4}{|c|}{ Percentage } & \multirow{2}{*}{$\begin{array}{l}\text { Chi- } \\
\text { squar } \\
\text { e }\end{array}$} & \multirow{2}{*}{ df } & \multirow{2}{*}{$\begin{array}{l}\text { Asymp } \\
\text {. Sig. }\end{array}$} \\
\hline & & & & $\begin{array}{l}\text { S. } \\
\text { Agr. }\end{array}$ & Agr. & $\begin{array}{l}\text { D.A } \\
\text { gr }\end{array}$ & $\begin{array}{l}\text { S. D. } \\
\text { Agr }\end{array}$ & & & \\
\hline $\begin{array}{l}\text { 21. The } \mathrm{CB} \text { includes lessons that reflect on study } \\
\text { techniques such as vocabulary learning techniques }\end{array}$ & 100 & 2.83 & .90 & 23 & 47 & 20 & 10 & 29.52 & 3 & .00 \\
\hline $\begin{array}{l}\text { 22. The CB contains advice on study skills } \\
\text { development. }\end{array}$ & 100 & 2.72 & .80 & 13 & 55 & 23 & 9 & 52.16 & 3 & .00 \\
\hline $\begin{array}{l}\text { 23. Students are encouraged to take some degree of } \\
\text { responsibility for their learning. }\end{array}$ & 100 & 2.92 & .89 & 27 & 47 & 17 & 9 & 32.32 & 3 & .00 \\
\hline $\begin{array}{l}\text { 24. There are some materials for independent work in } \\
\text { each unit. }\end{array}$ & 100 & 3.28 & .83 & 47 & 39 & 9 & 5 & 53.44 & 3 & .00 \\
\hline
\end{tabular}

Table 14 displays that in item 21, 23\% of the students strongly agreed and 47\% of them agreed that Top Notch coursebook includes lessons that reflect on study techniques such as vocabulary learning techniques. In addition, $20 \%$ of the students disagreed and $10 \%$ of them strongly disagreed with this item $(\mathrm{M}=2.83, \mathrm{SD}=.90$; SUM. of $\mathrm{S}$. Agr. \&Agr. $=70 \%$ ). Moreover, there is a significant difference between the number of students who agreed and the ones who strongly agreed, disagreed and strongly disagreed with this item, $\mathrm{c}^{2}(3, \mathrm{~N}=100)=29.52, \mathrm{p}<.05$.

Item 22 considers if Top Notch coursebook contains advice on study skills development. The findings indicate that $13 \%$ of the students strongly agreed and 55\% of them agreed that the coursebook contains advice on study skills development. In addition, $23 \%$ of the students disagreed and $9 \%$ of them strongly disagreed with this item $(\mathrm{M}=2.72$, $\mathrm{SD}=.80$; SUM. of S. Agr. \&Agr. = 68\%). Moreover, there is a significant difference between the number of students who agreed and the ones who strongly agreed, disagreed and strongly disagreed with this item, $\mathrm{c}^{2}(3, \mathrm{~N}=100)=$ $52.16, \mathrm{p}<.05$.

In item 23, 27\% of the students strongly agreed and 47\% of them agreed that students are encouraged to take some degree of responsibility for their learning. In addition, $17 \%$ of the students disagreed and $9 \%$ of them strongly disagreed with this item $(\mathrm{M}=2.92, \mathrm{SD}=.89$; SUM. of $\mathrm{S}$. Agr. \&Agr. $=74 \%)$. Moreover, there is a significant difference between the number of students who agreed and the ones who strongly agreed, disagreed and strongly disagreed with this item, $\mathrm{c}^{2}(3, \mathrm{~N}=100)=32.32, \mathrm{p}<.05$.

Item 24 considers whether there are some materials for independent work in each unit or not. The findings show that $47 \%$ of the students strongly agreed and 39\% of them agreed that there are some materials for independent work in each unit. In addition, 9\% of the students disagreed and 5\% of them strongly disagreed with this item $(\mathrm{M}=3.28$, $\mathrm{SD}=.83$; SUM. of S. Agr. \&Agr. = 86\%). Moreover, there is a significant difference between the number of students who agreed and the ones who strongly agreed, disagreed and strongly disagreed with this item, $\mathrm{c}^{2}(3, \mathrm{~N}=100)=$ $53.44, \mathrm{p}<.05$. 
Table 15. Result of the descriptive statistics, percentage and Chi-square of the teachers'responses related to visuals

\begin{tabular}{|c|c|c|c|c|c|c|c|c|c|c|}
\hline & & & Std & Perce & tage & & & Chi- & & $\Delta \mathrm{SV}$ \\
\hline & $\mathrm{N}$ & Mean & Deviation & $\begin{array}{l}\text { S. } \\
\text { Agr. }\end{array}$ & Agr. & $\begin{array}{l}\text { D.A } \\
\text { gr }\end{array}$ & $\begin{array}{l}\text { S. D. } \\
\text { Agr }\end{array}$ & $\begin{array}{l}\text { squar } \\
\text { e }\end{array}$ & df & Sig. \\
\hline 25. The textbook has attractive layout. & 20 & 2.80 & .89 & 20 & 50 & 20 & 10 & 7.20 & 3 & .07 \\
\hline $\begin{array}{l}\text { 26. The font size and type used in the book are } \\
\text { appropriate. }\end{array}$ & 20 & 3.20 & .77 & 35 & 55 & 5 & 5 & 14.40 & 3 & .00 \\
\hline $\begin{array}{l}\text { 27. The visuals are reasonably well produced and } \\
\text { attractive. }\end{array}$ & 20 & 2.95 & .89 & 30 & 40 & 25 & 5 & 5.20 & 3 & .16 \\
\hline
\end{tabular}

As demonstrated in table 15, in item 25, 20\% of the teachers strongly agreed and 50\% of them agreed that the textbook has attractive layout. In addition, $20 \%$ of the teachers disagreed and $10 \%$ of them strongly disagreed with this item (M $=2.80, \mathrm{SD}=.89$; SUM. of S. Agr. \&Agr. $=70 \%$ ). Moreover, there is no significant difference between the number of teachers who agreed and the ones who strongly agreed, disagreed, and strongly disagreed with this item, $\mathrm{c}^{2}(3, \mathrm{~N}=$ $20)=7.20, p>.05$.

In item $26,35 \%$ of the teachers strongly agreed and 55\% of them agreed that the font size and type used in the book are appropriate. Moreover, 5\% of the teachers disagreed and 5\% of them strongly disagreed with this item $(\mathrm{M}=$ 3.20, SD=.77; SUM. of S. Agr. \&Agr. =90\%). In addition, there is a significant difference between the number of teachers who agreed and the ones who strongly agreed, disagreed and strongly disagreed with this item, $\mathrm{c}^{2}(3, \mathrm{~N}=20)$ $=14.40, \mathrm{p}<.05$.

The 27 th item considers if the visuals are reasonably well produced and attractive. The results indicate that $30 \%$ of the teachers strongly agreed and 40\% of them agreed that the visuals are reasonably well produced and attractive. Moreover, $25 \%$ of the teachers disagreed and 5\% of them strongly disagreed with this item $(\mathrm{M}=2.95$, $\mathrm{SD}=.89$; SUM. of S. Agr. \&Agr. $=70 \%$ ). In addition, there is no significant difference between the number of teachers who agreed and the ones who strongly agreed, disagreed and strongly disagreed with this item, $c^{2}(3, N=20)=5.20$, $p$ $>.05$.

Table 16. Result of the descriptive statistics, percentage and Chi-square of the students'responses related to visuals

\begin{tabular}{|c|c|c|c|c|c|c|c|c|c|}
\hline & \multirow[b]{2}{*}{$\mathrm{N}$} & \multirow[b]{2}{*}{ Mean } & \multirow{2}{*}{$\begin{array}{l}\text { Std. } \\
\text { Deviation }\end{array}$} & \multicolumn{4}{|c|}{ Percentage } & \multirow{2}{*}{$\begin{array}{l}\text { Chi- } \\
\text { squar df } \\
\mathrm{e}\end{array}$} & \multirow{2}{*}{$\begin{array}{l}\text { Asymp } \\
\text {. Sig. }\end{array}$} \\
\hline & & & & $\begin{array}{l}\text { S. } \\
\text { Agr. }\end{array}$ & Agr. & $\begin{array}{l}\text { D.A } \\
\text { gr }\end{array}$ & $\begin{array}{l}\text { S. D. } \\
\text { Agr }\end{array}$ & & \\
\hline 25. The textbook has attractive layout. & 100 & 3.22 & .86 & 45 & 37 & 13 & 5 & 43.523 & .00 \\
\hline $\begin{array}{l}\text { 26. The font size and type used in the book are } \\
\text { appropriate. }\end{array}$ & 100 & 3.50 & .67 & 59 & 33 & 7 & 1 & 84.803 & .00 \\
\hline $\begin{array}{l}\text { 27. The visuals are reasonably well produced and } \\
\text { attractive. }\end{array}$ & 100 & 3.15 & .82 & 37 & 46 & 12 & 5 & 46.163 & .00 \\
\hline
\end{tabular}

As it is displayed in table 16 , in item $25,45 \%$ of the students strongly agreed and $37 \%$ of them agreed that the textbook has attractive layout. In addition, $13 \%$ of the students disagreed and 5\% of them strongly disagreed with this item $(\mathrm{M}=$ 3.22, $\mathrm{SD}=.86$; SUM. of S. Agr. \&Agr. $=82 \%$ ). Moreover, there is a significant difference between the number of students who agreed and the ones who strongly agreed, disagreed and strongly disagreed with this item, $\mathrm{c}^{2}(3, \mathrm{~N}=$ $100)=43.52, \mathrm{p}<.05$.

Item 26 considers whether the font size and type used in the book are appropriate or not. The findings show that $59 \%$ of the students strongly agreed and 33\% of them agreed that the font size and type used in the book are appropriate. In addition, $7 \%$ of the students disagreed and $1 \%$ of them strongly disagreed with this item $(\mathrm{M}=3.50, \mathrm{SD}=.67 ; \mathrm{SUM}$. of S. Agr. \&Agr. $=92 \%$ ). Moreover, there is a significant difference between the number of students who agreed and the ones who strongly agreed, disagreed and strongly disagreed with this item, $\mathrm{c}^{2}(3, \mathrm{~N}=100)=84.80, \mathrm{p}<.05$.

In item $27,37 \%$ of the students strongly agreed and $46 \%$ of them agreed that the visuals are reasonably well produced and attractive. In addition, $12 \%$ of the students disagreed and $5 \%$ of them strongly disagreed with this item $(\mathrm{M}=3.15$, $\mathrm{SD}=.82$; SUM. of S. Agr. \&Agr. = 83\%). Moreover, there is a significant difference between the number of students 
who agreed and the ones who strongly agreed, disagreed and strongly disagreed with this item, $\mathrm{c}^{2}(3, \mathrm{~N}=100)=$ 46.16, $\mathrm{p}<.05$.

Table 17. Result of the descriptive statistics, percentage and Chi-square of the teachers'responses related to practice and testing

\begin{tabular}{llllll} 
& & \multicolumn{2}{l}{ Percentage } & \multicolumn{2}{c}{ Chi- } \\
N Mean & $\begin{array}{l}\text { Std. } \\
\text { Deviation }\end{array}$ & $\begin{array}{l}\text { S. } \\
\text { Agr. }\end{array}$ & Agr. D.A S. D. & squar df $\begin{array}{l}\text { Asymp } \\
\text { gr Agr }\end{array}$ & e
\end{tabular}

28. The CB provides communicative exercises that enable learners to carry out their communicative tasks in real-life situations.

$\begin{array}{lll}20 & 2.70 \quad 92\end{array}$

29. There are directions to explain how every exercise can be done.

30. The number of exercises is suitable.
$20 \quad 3.00$

$20 \quad 3.15$
$20 \quad 40 \quad 30 \quad 10$

$4.00 \quad 3$ .26 $\begin{array}{llllll}20 & 50 & 25 & 5 & 8.40 & 3\end{array}$

25$$
50
$$

25

31. The textbook provides appropriate periodical tests for diagnostic purposes.

$\begin{array}{llllllll}.67 & 30 & 55 & 15 & 0 & 4.90 & 2 & .09\end{array}$

As shown in table 17, in item 28, 20\% of the teachers strongly agreed and $40 \%$ of them agreed that Top Notch coursebook provides communicative exercises that enable learners to carry out their communicative tasks in real-life situations. Moreover, $30 \%$ of the teachers disagreed and $10 \%$ of them strongly disagreed with this item $(\mathrm{M}=2.70$, $\mathrm{SD}=.92$; SUM. of S. Agr. \&Agr. $=60 \%$ ). In addition, there is no significant difference between the number of teachers who agreed and the ones who strongly agreed, disagreed and strongly disagreed with this item, $c^{2}(3, N=20)=4.00, p$ $>.05$.

In item $29,20 \%$ of the teachers strongly agreed and 50\% of them agreed that there are directions to explain how every exercise can be done. Moreover, 25\% of the teachers disagreed and 5\% of them strongly disagreed with this item $(\mathrm{M}=$ 2.85, $\mathrm{SD}=.81$; SUM. of S. Agr. \&Agr. $=70 \%$ ). In addition, there is a significant difference between the number of teachers who agreed and the ones who strongly agreed, disagreed and strongly disagreed with this item, $\mathrm{c}^{2}(3, \mathrm{~N}=20)$ $=8.40, \mathrm{p} \leqslant .05$.

Item 30 considers if the number of exercises is suitable. Data analysis shows that $25 \%$ of the teachers strongly agreed and $50 \%$ of them agreed that the number of exercises is suitable. Moreover, $25 \%$ of the teachers disagreed with this item $(\mathrm{M}=3.00, \mathrm{SD}=.72$; SUM. of S. Agr. \&Agr. $=75 \%)$. In addition, there is no significant difference between the number of teachers who agreed and the ones who strongly agreed and disagreed with this item, $c^{2}(2, N=20)=2.50, p$ $>.05$.

In item $31,30 \%$ of the teachers strongly agreed and 55\% of them agreed that the textbook provides appropriate periodical tests for diagnostic purposes. Moreover, $15 \%$ of the teachers disagreed with this item $(\mathrm{M}=3.15, \mathrm{SD}=.67$; SUM. of S. Agr. \&Agr. =85\%). In addition, there is no significant difference between the number of teachers who agreed and the ones who strongly agreed and disagreed with this item, $\mathrm{c}^{2}(2, \mathrm{~N}=20)=4.90, \mathrm{p}>.05$.

Table 18. Result of the descriptive statistics, percentage and Chi-square of the students'responses related to practice and testing

\begin{tabular}{|c|c|c|c|c|c|c|c|c|c|}
\hline & \multirow[b]{2}{*}{$\mathrm{N}$} & \multirow[b]{2}{*}{ Mean } & \multirow{2}{*}{$\begin{array}{l}\text { Std. } \\
\text { Deviation }\end{array}$} & \multicolumn{4}{|c|}{ Percentage } & \multirow{2}{*}{$\begin{array}{l}\text { Chi- } \\
\text { squar } \\
\text { e }\end{array}$} & \multirow{2}{*}{$\begin{array}{l}\text { Asymp } \\
\text {. Sig. }\end{array}$} \\
\hline & & & & $\begin{array}{l}\text { S. } \\
\text { Agr. }\end{array}$ & Agr. & $\begin{array}{l}\text { D.A } \\
\text { gr }\end{array}$ & $\begin{array}{l}\text { S. D. } \\
\text { Agr }\end{array}$ & & \\
\hline $\begin{array}{l}\text { 28. The CB provides communicative exercises that } \\
\text { enable learners to carry out their communicative } \\
\text { tasks in real-life situations. }\end{array}$ & 100 & 2.95 & .89 & 29 & 45 & 18 & 8 & 30.163 & .00 \\
\hline $\begin{array}{l}\text { 29. There are directions to explain how every exercise } \\
\text { can be done. }\end{array}$ & 100 & 2.97 & .74 & 22 & 57 & 17 & 4 & 61.523 & .00 \\
\hline 30. The number of exercises is suitable. & 100 & 3.26 & .79 & 43 & 45 & 7 & 5 & $57.92^{3}$ & .00 \\
\hline
\end{tabular}


situations. In addition, $18 \%$ of the students disagreed and $8 \%$ of them strongly disagreed with this item $(\mathrm{M}=2.95$, $\mathrm{SD}=.89$; SUM. of S. Agr. \&Agr. = 74\%). Moreover, there is a significant difference between the number of students who agreed and the ones who strongly agreed, disagreed and strongly disagreed with this item, $\mathrm{c}^{2}(3, \mathrm{~N}=100)=$ $30.16, \mathrm{p}<.05$.

Item 29 considers if there are directions to explain how every exercise can be done. The results show that $22 \%$ of the students strongly agreed and 57\% of them agreed that there are directions to explain how every exercise can be done. In addition, $17 \%$ of the students disagreed and $4 \%$ of them strongly disagreed with this item $(\mathrm{M}=2.97, \mathrm{SD}=.74 ; \mathrm{SUM}$. of S. Agr. \&Agr. = 79\%). Moreover, there is a significant difference between the number of students who agreed and the ones who strongly agreed, disagreed and strongly disagreed with this item, $\mathrm{c}^{2}(3, \mathrm{~N}=100)=61.52, \mathrm{p} \leqslant .05$.

In the last item, $43 \%$ of the students strongly agreed and $45 \%$ of them agreed that the number of exercises is suitable. In addition, $7 \%$ of the students disagreed and 5\% of them strongly disagreed with this item $(\mathrm{M}=3.26, \mathrm{SD}=.79 ; \mathrm{SUM}$. of S. Agr. \&Agr. = 88\%). Moreover, there is a significant difference between the number of students who agreed and the ones who strongly agreed, disagreed and strongly disagreed with this item, $\mathrm{c}^{2}(3, \mathrm{~N}=100)=57.92, \mathrm{p}<.05$.

Table 19. Result of the descriptive statistics, percentage and Chi-square of the teachers'responses related to supplementary material

\begin{tabular}{|c|c|c|c|c|c|c|c|c|c|}
\hline & \multirow{2}{*}{$\mathrm{N}$} & \multirow{2}{*}{ Mean } & \multirow{2}{*}{$\begin{array}{l}\text { Std. } \\
\text { Deviation }\end{array}$} & \multicolumn{4}{|c|}{ Percentage } & \multirow{2}{*}{$\begin{array}{l}\text { Chi- } \\
\text { squar } \\
\text { e }\end{array}$} & \multirow{2}{*}{$\begin{array}{l}\text { df Asymp } \\
\text {. Sig. }\end{array}$} \\
\hline 1 & & & & $\begin{array}{l}\text { S. } \\
\text { Agr. }\end{array}$ & Agr. & $\begin{array}{l}\text { D.A } \\
\text { gr }\end{array}$ & $\begin{array}{l}\text { S. D. } \\
\text { Agr }\end{array}$ & & \\
\hline $\begin{array}{l}\text { 32. The supplementary material such as posters and } \\
\text { flash cards, etc. accompanying the book is attractive } \\
\text { and suitable. }\end{array}$ & 19 & 2.73 & .99 & 21.1 & 47.4 & 15.7 & 715.8 & 5.21 & 3.16 \\
\hline $\begin{array}{l}\text { 33. There is an appropriate teacher's guide to aid the } \\
\text { teacher. }\end{array}$ & 20 & 3.30 & .92 & 55 & 25 & 15 & 5 & 11.20 & 3.01 \\
\hline
\end{tabular}

As displayed in table 19, in item 32, 21.1\% of the teachers strongly agreed and $47.4 \%$ of them agreed that the supplementary material such as posters and flash cards, etc. accompanying the book is attractive and suitable. In addition, $15.7 \%$ of the teachers disagreed and $15.8 \%$ of them strongly disagreed with this item $(\mathrm{M}=2.73, \mathrm{SD}=.99$; SUM. of S. Agr. \&Agr. =68.5\%). Moreover, there is no significant difference between the number of teachers who agreed and the ones who strongly agreed, disagreed, and strongly disagreed with this item, $c^{2}(3, N=19)=5.21, p>$ .05 .

In item 33, 55\% of the teachers strongly agreed and 25\% of them agreed that there is an appropriate teacher's guide to aid the teacher. Moreover, $15 \%$ of the teachers disagreed and 5\% of them strongly disagreed with this item $(\mathrm{M}=3.30$, $\mathrm{SD}=.92$; SUM. of S. Agr. \&Agr. $=80 \%$ ). In addition, there is a significant difference between the number of teachers who strongly agreed and the ones who agreed, disagreed and strongly disagreed with this item, $\mathrm{c}^{2}(3, \mathrm{~N}=20)=11.20$, $\mathrm{p}<.05$.

Table 20. Result of the descriptive statistics, percentage and Chi-square of the teachers' responses related to objectives

\begin{tabular}{|c|c|c|c|c|c|c|c|c|c|c|}
\hline & \multirow[b]{2}{*}{$\mathrm{N}$} & \multirow[b]{2}{*}{ Mean } & \multirow{2}{*}{$\begin{array}{l}\text { Std. } \\
\text { Deviation }\end{array}$} & \multicolumn{4}{|c|}{ Percentage } & \multirow{2}{*}{$\begin{array}{l}\text { Chi- } \\
\text { squar } \\
\text { e }\end{array}$} & \multirow{2}{*}{$\mathrm{df}$} & \multirow{2}{*}{$\begin{array}{l}\text { Asymp } \\
\text { Sig. }\end{array}$} \\
\hline & & & & $\begin{array}{l}\text { S. } \\
\text { Agr. }\end{array}$ & Agr. & $\begin{array}{l}\text { D.A } \\
\text { gr }\end{array}$ & $\begin{array}{l}\text { S. D. } \\
\text { Agr }\end{array}$ & & & \\
\hline $\begin{array}{l}\text { 34. The terminal goals are specified in the Teacher's } \\
\text { Manual or the student's Book. }\end{array}$ & 19 & 3.00 & .88 & 31.6 & 42.1 & 21.1 & 5.2 & 5.63 & 3 & .13 \\
\hline $\begin{array}{l}\text { 35. The developmental objectives are specified at the } \\
\text { beginning of each lesson. }\end{array}$ & 20 & 3.10 & .91 & 35 & 50 & 5 & 10 & 10.80 & 3 & .01 \\
\hline $\begin{array}{l}\text { 36. Developmental objectives meet the needs of } \\
\text { learners. }\end{array}$ & 20 & 3.35 & .67 & 45 & 45 & 10 & 0 & 4.90 & 2 & .09 \\
\hline $\begin{array}{l}\text { 37. Developmental objectives suit the level of the } \\
\text { learners. }\end{array}$ & 20 & 3.05 & .69 & 25 & 55 & 20 & 0 & 4.30 & 2 & .12 \\
\hline
\end{tabular}

Table 20 shows that in item 34, 31.6\% of the teachers strongly agreed and 42.1\% of them agreed that the terminal goals are specified in the Teacher's Manual or the student's Book. Moreover, 21.1\% of the teachers disagreed and 5.2\% of them strongly disagreed with this item $(\mathrm{M}=3.00, \mathrm{SD}=.88$; $\mathrm{SUM}$. of $\mathrm{S}$. Agr. \&Agr. $=73.7 \%)$. In addition, there is no 
significant difference between the number of teachers who agreed and the ones who strongly agreed, disagreed and strongly disagreed with this item, $\mathrm{c}^{2}(3, \mathrm{~N}=19)=5.63, \mathrm{p}>.05$.

Item 35 considers if the developmental objectives are specified at the beginning of each lesson. The results indicate that $35 \%$ of the teachers strongly agreed and 50\% of them agreed that the developmental objectives are specified at the beginning of each lesson. Moreover, $5 \%$ of the teachers disagreed and $10 \%$ of them strongly disagreed with this item $(\mathrm{M}=3.10, \mathrm{SD}=.91$; SUM. of S. Agr. \&Agr. =85\%). In addition, there is a significant difference between the number of teachers who agreed and the ones who strongly agreed, disagreed and strongly disagreed with this item, $\mathrm{c}^{2}(3, \mathrm{~N}=20)$ $=10.80, \mathrm{p}<.05$.

In item $36,45 \%$ of the teachers strongly agreed and $45 \%$ of them agreed that developmental objectives meet the needs of learners. Moreover, $10 \%$ of the teachers disagreed with this item $(\mathrm{M}=3.35, \mathrm{SD}=.67$; SUM. of S. Agr. \&Agr. $=90 \%$ ). In addition, there is no significant difference between the number of teachers who agreed and the ones who strongly agreed and disagreed with this item, $\mathrm{c}^{2}(2, \mathrm{~N}=20)=4.90, \mathrm{p}>.05$.

In the last item of this category, $25 \%$ of the teachers strongly agreed and $55 \%$ of them agreed that developmental objectives suit the level of the learners. Moreover, $20 \%$ of the teachers disagreed with this item $(\mathrm{M}=3.05, \mathrm{SD}=.69$; SUM. of S. Agr. \&Agr. $=80 \%$ ). Moreover, there is no significant difference between the number of teachers who agreed and the ones who strongly agreed and disagreed with this item, $\mathrm{c}^{2}(2, \mathrm{~N}=20)=4.30, \mathrm{p}>.05$.

Table 21. Result of the descriptive statistics, percentage and Chi-square of the teachers'responses related to content selection

\begin{tabular}{|c|c|c|c|c|c|c|c|c|c|}
\hline & \multirow[b]{2}{*}{$\mathrm{N}$} & \multirow[b]{2}{*}{ Mean } & \multirow{2}{*}{$\begin{array}{l}\text { Std. } \\
\text { Deviation }\end{array}$} & \multicolumn{4}{|c|}{ Percentage } & \multirow{2}{*}{$\begin{array}{l}\text { Chi- } \\
\text { squar } \\
\text { e }\end{array}$} & \multirow{2}{*}{$\begin{array}{l}\text { df Asymp } \\
\text {. Sig. }\end{array}$} \\
\hline & & & & $\begin{array}{l}\text { S. } \\
\text { Agr. }\end{array}$ & Agr. & $\begin{array}{l}\text { D.A } \\
\text { gr }\end{array}$ & $\begin{array}{l}\text { S. D. } \\
\text { Agr }\end{array}$ & & \\
\hline $\begin{array}{l}\text { 34. Content selection reflects the objectives of the } \\
\text { course. }\end{array}$ & 20 & 3.05 & .51 & 15 & 75 & 10 & 0 & 15.70 & 2.00 \\
\hline 35. Content selection suits the level of the course. & 20 & 3.00 & .79 & 25 & 55 & 15 & 5 & 11.20 & 3.01 \\
\hline $\begin{array}{l}\text { 36. Content selection suits the time limit allowed for } \\
\text { the course. }\end{array}$ & 20 & 2.85 & .93 & 25 & 45 & 20 & 10 & 5.20 & 3.16 \\
\hline
\end{tabular}

As indicated in table 21, in item 38, 15\% of the teachers agreed and 75\% of them disagreed that content selection reflects the objectives of the course. Moreover, $10 \%$ of the teachers disagreed with this item $(\mathrm{M}=3.05, \mathrm{SD}=.51 ; \mathrm{SUM}$. of S. Agr. \&Agr. =90\%). In addition, there is a significant difference between the number of teachers who agreed and the ones who strongly agreed and disagreed with this item, $\mathrm{c}^{2}(2, \mathrm{~N}=20)=15.70, \mathrm{p}<.05$.

Item 39 considers whether content selection suits the level of the course or not. Data analysis shows that $25 \%$ of the teachers strongly agreed and 55\% of them agreed that content selection suits the level of the course. Moreover, 15\% of the teachers disagreed and $5 \%$ of them strongly disagreed with this item $(\mathrm{M}=3.00, \mathrm{SD}=.79$; SUM. of S. Agr. \&Agr. $=80 \%$ ). In addition, there is a significant difference between the number of teachers who agreed and the ones who strongly agreed, disagreed and strongly disagreed with this item, $\mathrm{c}^{2}(3, \mathrm{~N}=20)=11.20, \mathrm{p} \leqslant .05$.

In item 40, 25\% of the teachers strongly agreed and 45\% of them agreed that content selection suits the time limit allowed for the course. Moreover, $20 \%$ of the teachers disagreed and $10 \%$ of them strongly disagreed with this item (M $=2.85, \mathrm{SD}=.93$; SUM. of S. Agr. \&Agr. $=70 \%$ ). Moreover, there is no significant difference between the number of teachers who agreed and the ones who strongly agreed, disagreed and strongly disagreed with this item, $\mathrm{c}^{2}(3, \mathrm{~N}=20)$ $=5.20, \mathrm{p}>.05$.

Table 22. Result of the descriptive statistics, percentage and Chi-square of the teachers'responses related to gradation

\begin{tabular}{|c|c|c|c|c|c|c|c|c|}
\hline & \multirow[b]{2}{*}{$\mathrm{N}$} & \multirow[b]{2}{*}{ Mean } & \multirow{2}{*}{$\begin{array}{l}\text { Std. } \\
\text { Deviation }\end{array}$} & \multicolumn{4}{|c|}{ Percentage } & \multirow{2}{*}{$\begin{array}{l}\text { Chi- } \\
\neg \text { squar df Asymp } \\
\mathrm{e}\end{array}$} \\
\hline & & & & $\begin{array}{l}\text { S. } \\
\text { Agr. }\end{array}$ & Agr. & $\begin{array}{l}\text { D.A } \\
\text { gr }\end{array}$ & $\begin{array}{l}\text { S. D. } \\
\text { Agr }\end{array}$ & \\
\hline 41. The grading of items is suitable for the learners. & 20 & 2.70 & .73 & 10 & 55 & 30 & 5 & $\begin{array}{lll}12.40 & 3 & .01\end{array}$ \\
\hline
\end{tabular}

As demonstrated in table 22, in item $41,10 \%$ of the teachers strongly agreed and 55\% of them agreed that the grading of items is suitable for the learners. Moreover, $30 \%$ of the teachers disagreed and $5 \%$ of them strongly disagreed with this item $(\mathrm{M}=2.70, \mathrm{SD}=.73$; SUM. of $\mathrm{S}$. Agr. \&Agr. $=65 \%)$. In addition, there is a significant difference between the number of teachers who agreed and the ones who strongly agreed,disagreed and strongly disagreed with this item, $\mathrm{c}^{2}$ $(3, \mathrm{~N}=20)=12.40, \mathrm{p}<.05$. 
Table 23. Result of the descriptive statistics, percentage and Chi-square of the teachers' responses related to culture

\begin{tabular}{|c|c|c|c|c|c|c|c|c|c|c|}
\hline & \multirow[b]{2}{*}{$\mathrm{N}$} & \multirow[b]{2}{*}{ Mean } & \multirow{2}{*}{$\begin{array}{l}\text { Std. } \\
\text { Deviation }\end{array}$} & \multicolumn{4}{|c|}{ Percentage } & \multirow{2}{*}{$\begin{array}{l}\text { Chi- } \\
\neg \text { squar } \\
\mathrm{e}\end{array}$} & \multirow[b]{2}{*}{$\mathrm{df}$} & \multirow{2}{*}{$\begin{array}{l}\text { Asymp } \\
\text { Sig. }\end{array}$} \\
\hline & & & & $\begin{array}{l}\text { S. } \\
\text { Agr. }\end{array}$ & Agr. & $\begin{array}{l}\text { D.A } \\
\text { gr }\end{array}$ & $\begin{array}{l}\text { S. D. } \\
\text { Agr }\end{array}$ & & & \\
\hline $\begin{array}{l}\text { 42. The coursebook aims to alienate students from } \\
\text { their own culture. }\end{array}$ & 20 & 2.20 & .95 & 10 & 25 & 40 & 25 & 3.60 & 3 & .31 \\
\hline $\begin{array}{l}\text { 43. The coursebook is a vehicle to advertise the } \\
\text { Anglo-American culture. }\end{array}$ & 20 & 2.45 & .94 & 15 & 30 & 40 & 15 & 3.60 & 3 & .31 \\
\hline $\begin{array}{l}\text { 44. The illustrations are culturally appropriate to the } \\
\text { students. }\end{array}$ & 20 & 3.10 & .55 & 20 & 70 & 10 & 0 & 12.40 & 2 & .00 \\
\hline $\begin{array}{l}\text { 45. It is possible to involve the local culture and } \\
\text { language in the textbook. }\end{array}$ & 20 & 2.70 & .98 & 20 & 45 & 20 & 15 & 4.40 & 3 & .22 \\
\hline $\begin{array}{l}\text { 46. The coursebook is in line with promoting the } \\
\text { concept of World Englishes (WE). }\end{array}$ & 20 & 2.75 & .44 & 0 & 75 & 25 & 0 & 5.00 & 1 & .03 \\
\hline 47. Cultural sensitivities have been considered. & 19 & 2.94 & .70 & 15.8 & 68.4 & 10.5 & 5.3 & 19.52 & 3 & .00 \\
\hline 48. It takes religious considerations into account. & 20 & 2.85 & .74 & 15 & 60 & 20 & 5 & 14.00 & 3 & .00 \\
\hline 49. It is free from ideological tendencies. & 20 & 2.70 & .80 & 15 & 45 & 35 & 5 & 8.00 & 3 & .06 \\
\hline $\begin{array}{l}\text { 50. It raises awareness by avoiding or realizing } \\
\text { cultural stereotypes }\end{array}$ & 18 & 3.05 & .64 & 16.7 & 77.8 & 0 & 5.6 & 16.33 & 2 & .00 \\
\hline $\begin{array}{l}\text { 51. It prepares students to interact with people from } \\
\text { other cultures. }\end{array}$ & 19 & 3.37 & .68 & 47.4 & 42.1 & 10.5 & 0 & 4.52 & 2 & .10 \\
\hline 52. It aims at international culture & 20 & 3.15 & .87 & 40.0 & 40.0 & 15.0 & 5.0 & 7.60 & 3 & .06 \\
\hline $\begin{array}{l}\text { 53. The social and cultural contexts in the coursebook } \\
\text { are comprehensible to the learners. }\end{array}$ & 20 & 3.35 & .59 & 40.0 & 55.0 & 5.0 & 0 & 7.90 & 2 & .02 \\
\hline
\end{tabular}

As can be seen in table 23, in item $42,10 \%$ of the teachers strongly agreed and $25 \%$ of them agreed that Top Notch coursebook aims to alienate students from their own culture. In addition, $40 \%$ of the teachers disagreed and $25 \%$ of them strongly disagreed with this item $(\mathrm{M}=2.20, \mathrm{SD}=.95$; SUM. of D. Agr. \&S. D. Agr. $=65 \%)$. Moreover, there is no significant difference between the number of teachers who disagreed and the ones who strongly agreed, agreed, and strongly disagreed with this item, $\mathrm{c}^{2}(3, \mathrm{~N}=20)=3.60, \mathrm{p}>.05$.

Item 43 considers if Top Notch coursebook is a vehicle to advertise the Anglo-American culture. The results show that $15 \%$ of the teachers strongly agreed and 30\% of them agreed that the coursebook is a vehicle to advertise the AngloAmerican culture. In addition, $40 \%$ of the teachers disagreed and $15 \%$ of them strongly disagreed with this item $(\mathrm{M}=$ 2.45, SD=.94; SUM. of D. Agr. \&S. D. Agr. =55\%). Moreover, there is no significant difference between the number of teachers who disagreed and the ones who strongly agreed, agreed, and strongly disagreed with this item, $\mathrm{c}^{2}(3, \mathrm{~N}=$ $20)=3.60, \mathrm{p}>.05$.

In item 44, 20\% of the teachers strongly agreed and 70\% of them agreed that the illustrations are culturally appropriate to the students. In addition, $10 \%$ of the teachers disagreed with this item $(\mathrm{M}=3.10, \mathrm{SD}=.55 ; \mathrm{SUM}$. of $\mathrm{S}$. Agr. \&Agr. $=90 \%$ ). In addition, there is a significant difference between the number of teachers who agreed and the ones who strongly agreed and disagreed with this item, $\mathrm{c}^{2}(2, \mathrm{~N}=20)=12.40, \mathrm{p}<.05$.

Item 45 considers whether it is possible to involve the local culture and language in the textbook or not. Data analysis indicates that $20 \%$ of the teachers strongly agreed and $45 \%$ of them agreed that it is possible to involve the local culture and language in the textbook. Moreover, $20 \%$ of the teachers disagreed and $15 \%$ of them strongly disagreed with this 
item $(\mathrm{M}=2.70, \mathrm{SD}=.98$; SUM. of S. Agr. \&Agr. $=65 \%)$. In addition, there is no significant difference between the number of teachers who agreed and the ones who strongly agreed, disagreed and strongly disagreed with this item, $\mathrm{c}^{2}$ $(3, \mathrm{~N}=20)=4.40, \mathrm{p}>.05$.

In item $46,75 \%$ of the teachers agreed and $25 \%$ of them disagreed that Top Notch coursebook is in line with promoting the concept of World Englishes (WE) $(\mathrm{M}=2.75, \mathrm{SD}=.44)$. In addition, there is a significant difference between the number of teachers who agreed and the ones who disagreed with this item, $\mathrm{c}^{2}(1, \mathrm{~N}=20)=5.00, \mathrm{p}<.05$.

Item 47 indicates that $15.8 \%$ of the teachers strongly agreed and $68.4 \%$ of them agreed thatcultural sensitivities have been considered. In addition, $10.5 \%$ of the teachers disagreed and $5.3 \%$ of them strongly disagreed with this item $(\mathrm{M}=$ 2.94, $\mathrm{SD}=.70$; SUM. of S. Agr. \&Agr. $=84.2 \%$ ). In addition, there is a significant difference between the number of teachers who agreed and the ones who strongly agreed, disagreed, and strongly disagreed with this item, $\mathrm{c}^{2}(3, \mathrm{~N}=$ $19)=19.52, p<.05$.

In item $48,15 \%$ of the teachers strongly agreed and $60 \%$ of them agreed that Top Notch coursebook takes religious considerations into account. In addition, $20 \%$ of the teachers disagreed and $5 \%$ of them strongly disagreed with this item $(\mathrm{M}=2.85, \mathrm{SD}=.74$; SUM. of $\mathrm{S}$. Agr. \&Agr. $=75 \%)$. In addition, there is a significant difference between the number of teachers who agreed and the ones who strongly agreed, disagreed and strongly disagreed with this item, $\mathrm{c}^{2}$ $(3, \mathrm{~N}=20)=14.00, \mathrm{p}<.05$.

Item 49 considers if the coursebook is free from ideological tendencies. The results show that $15 \%$ of the teachers strongly agreed and $45 \%$ of them agreed that Top Notch coursebook is free from ideological tendencies. Moreover, $35 \%$ of the teachers disagreed and $5 \%$ of them strongly disagreed with this item $(\mathrm{M}=2.70, \mathrm{SD}=.80$; SUM. of S. Agr. \&Agr. $=60 \%$ ). In addition, there is no significant difference between the number of teachers who agreed and the ones who strongly agreed, disagreed and strongly disagreed with this item, $\mathrm{c}^{2}(3, \mathrm{~N}=20)=8.00, \mathrm{p}>.05$.

In item $50,16.7 \%$ of the teachers strongly agreed and $77.8 \%$ of them agreed that the coursebook raises awareness by avoiding or realizing cultural stereotypes. Moreover, $5.5 \%$ of the teachers strongly disagreed with this item $(\mathrm{M}=3.05$, $\mathrm{SD}=.64$; SUM. of S. Agr. \&Agr. $=94.5 \%$ ). In addition, there is a significant difference between the number of teachers who agreed and the ones who strongly agreed and strongly disagreed with this item, $c^{2}(2, N=18)=16.33, p<.05$.

Item 51 considers if the coursebook prepares students to interact with people from other cultures. Data analysis shows that $47.4 \%$ of the teachers strongly agreed and $42.1 \%$ of them agreed that Top Notch coursebook prepares students to interact with people from other cultures. Moreover, $10.5 \%$ of the teachers disagreed with this item $(\mathrm{M}=3.37, \mathrm{SD}=.68$; SUM. of S. Agr. \&Agr. $=89.5 \%$ ). In addition, there is no significant difference between the number of teachers who agreed and the ones who strongly agreed and disagreed with this item, $\mathrm{c}^{2}(2, \mathrm{~N}=19)=4.52, \mathrm{p}>.05$.

In item $52,40 \%$ of the teachers strongly agreed and $40 \%$ of them agreed that Top Notch coursebook aims at international culture. Moreover, $15 \%$ of the teachers disagreed and $5 \%$ of them strongly disagreed with this item $(\mathrm{M}=$ $3.15, \mathrm{SD}=.87$; SUM. of S. Agr. \&Agr. $=80 \%$ ). In addition, there is no significant difference between the number of teachers who agreed and the ones who strongly agreed and disagreed with this item, $\mathrm{c}^{2}(2, \mathrm{~N}=20)=7.60, \mathrm{p}>.05$.

The last item of the category, $40 \%$ of the teachers strongly agreed and $55 \%$ of them agreed that the social and cultural contexts in the coursebook are comprehensible to the learners. Moreover, $5 \%$ of the teachers disagreed with this item $(\mathrm{M}=3.35, \mathrm{SD}=.59$; SUM. of S. Agr. \&Agr. $=95 \%)$. In addition, there is a significant difference between the number of teachers who agreed and the ones who strongly agreed and disagreed with this item, $c^{2}(2, N=20)=7.90, p<.05$.

\subsection{Analysis of the Interviews}

In order to empower the gathered data, the researcher interviewed 25 percent of the teachers and 10 percent of the students who have participated in this study. The findings of these interviews were employed in extracting strengths and weaknesses of the coursebooks in section 5.1.2. Moreover, a brief report of the interviewees' comments is presented below.

In the case of Top Notch, the teachers and students expressed their satisfaction with approximately all parts of the book including content, grammar, methodology, pronunciation, etc. and none of them mentioned any demerits for the coursebook.

\section{Discussion of the Findings}

In the following, each research question is presented and discussed thoroughly.

\subsection{Research Question 1}

\section{How is Top Notch series viewed from language teachers' and students' perspectives?}

In the case of all categories, teachers as well as students had approximately similar ideas. However, some differences could be identified.

In terms of content, teachers had less agreement with contextualizing language items in Top Notch. The findings regarding content from teachers' perspective Top Notch are in line with the results of Rezaee, Kouhpaeenejad, and Mohammadi (2013) who evaluated two series of ELT coursebook: Interchange ( $3^{\text {rd }}$ edition $)$ and Top Notch ( $2^{\text {nd }}$ edition). In their study, most students agreed that the grammar points and vocabulary items are introduced in motivating and realistic contexts in Interchange series but it is not the case in Top Notchtextbooks. Their results also show that the subject and content of Top Notch series is interesting, challenging and motivating and there is a sufficient variety in the 
subject and content of Top Notch textbooks. Regarding students' point of view, the findings are in line with the results of EslamiRasekh et al. (2010). They came to the conclusion that the themes and topics students find in Top Notch seem to motivate the audience. The title/topic of the units found in Top Notch are more tangible and worldly, for instance Names and occupations, directions and transportation.

Regarding grammar, teachers believed that Top Notch providedclear and simple paradigms used to introduce grammatical rules, and also suitable grammar items for students' language needs.The results achieved from students' perspective are not in line with the findings of Rezaee, Kouhpaeenejad, and Mohammadi (2013). In their study most students believed that the grammar points were presented with brief and easy examples and explanations in Top Notch coursebook.

Considering vocabulary, both teachers and students agreed that Top Notch did well inusing new lexical items in the following units, and having adequate exercises for vocabulary. In the case of phonology, teachers and students believed that the coursebook made use of different types of activities, such as listening, dialogue practice etc. for building pronunciation. Moreover, they also agreed that the coursebook used adequate amount of pronunciation practice.

In regard to language skills, they believed that Top Notch practiced all four language skills of listening, speaking, reading, and writing in each unit. Such findings are consistent with Rezaee, Kouhpaeenejad, and Mohammadi's (2013) results. They found out that most students highly agree that the language used in the textbooks is authentic.

Considering methodology, students believed that Top Notch encourages inductive approach to learning and balance accuracy with fluency. The findings regarding the balance of accuracy with fluency in Top Notch are compatible with the results of Rezaee, Kouhpaeenejad, and Mohammadi (2013) who found out that students agree with the opinion that in Top Notch, there is an even distribution of tasks that focus on both fluent and accurate production.

Regarding study skills, teachers agreed that there are some materials for independent work in each unit of Top Notch..

In the case of visuals, teachers highly agreed that the visuals in Top Notch are reasonably well produced and attractive. Moreover, they agreed that Top Notch hasan attractive which is compatible with the findings of Rezaee, Kouhpaeenejad, and Mohammadi (2013) who found out that nearly most students were of the belief that the layout and design of Top Notchtextbooks is appropriate and clear and the textbooks are organized effectively. Having been compatible with this study's results from students' perspective, EslamiRasekh et al. (2010) found out that the most lively, colorful, and authentic photographs and pictures are seen in Top Notch.

In regard to practice and testing, both teachers and students agreed that Top Notchprovided suitable number of exercises and more appropriate periodical tests for diagnostic purposes.

Regarding supplementary materials, teachers agreed that the supplementary material such as posters and flash cards, etc. accompanying Top Notch is attractive and suitable.

In regard to culture, teachers had less agreement that Top Notch is a vehicle to advertise the Anglo-American culture. In addition, they believed that the illustrations in Top Notch are culturally more appropriate to the students than the other coursebooks under investigation. In the teachers' ideas, cultural sensitivities and religious considerations in Top Notch were taken into account and the coursebook prepares students to interact with people from other cultures. Also, agreed that the social and cultural contexts in Top Notch are comprehensible to the learners.

In the case of Top Notch, the results of the present study is in line with the findings of Rezaee, Kouhpaeenejad, and Mohammadi (2013) who found out that the students felt that the coursebook is not culturally biased and they does not portray any negative stereotypes in this series. The results are also consistent with the findings of EslamiRasekh et al. (2010). They concluded that Top Notch is not culturally biased in anyway. They try to use a variety of information from different cultures and nationalities.

\subsection{Research Question 2}

In the following section, the researcher extracted the strengths and weaknesses of the coursebook from both teachers and students point of view based on the amount of mean. The items with the mean more than 3.1 were considered as strength and the items with the mean below 2.4 as weakness. It is worth noting that the items 42,43 and 48 , due to their negative concept, are scored reversely.

\subsubsection{Strengths of Top Notch from Students' Perspective}

1. Texts and dialogues include new vocabulary and grammatical structures.

2. Language items (e.g. vocabulary, etc) are presented in context to make meaning clear.

3. The paradigm used to introduce grammatical rules is clear and simple.

4. Sentences and examples contain words that are known by learners.

5. Pronunciation is built through different types of activities, such as listening, dialogue practice etc.

6. All four language skills of listening, speaking, reading, and writing are practiced in each unit.

7. There are some materials for independent work in each unit.

8. The textbook has attractive layout.

9. The font size and type used in the book are appropriate. 
10. The visuals are reasonably well produced and attractive.

11. The number of exercises is suitable.

A large number of strengths and lack of any weaknesses is indicator of students' general satisfaction with Top Notch coursebook. In students' beliefs, inclusion of new vocabulary and grammatical structures, contextualizing vocabulary, simplicity of examples, attractive layout, etc. are some of the features which distinguished Top Notch from the other coursebooks under investigation.

\subsubsection{Strengths of Top Notch from Teachers' Perspective}

1. Texts and dialogues include new vocabulary and grammatical structures.

2. The paradigm used to introduce grammatical rules is clear and simple.

3. Grammar items suit students' language needs.

4. The font size and type used in the book are appropriate.

5. The number of exercises is suitable.

6. There is an appropriate teacher's guide to aid the teacher.

7. Developmental objectives meet the needs of learners.

8. The coursebook does not aim to alienate students from their own culture.

9. It does not take religious considerations into account.

10. It prepares students to interact with people from other cultures.

11. It aims at international culture.

12. The social and cultural contexts in the coursebook are comprehensible to the learners.

Same as students, teachers also expressed good satisfaction with many part of Top Notch coursebook including grammar, practice and testing, visuals, objectives, and culture. High satisfaction of teachers and students indicate that Top Notch seems to be the best coursebook among the other coursebooks under investigation from teachers' and students' point of view.

\section{Conclusion}

In conclusion, the researcher does not propose that one coursebook should replace another but that teachers should be well aware of strengths and weaknesses of the coursebook they teach. In other words, it is important to consider which coursebook may best support language learners in diverse instructional contexts.

\section{References}

Brown, J. (1995). The Elements of Language Curriculum. Boston:Heinle and Heinle Publishers.

Cunningsworth, A. (1984). Evaluating and selecting ELT materials. London: Heinemann.

Cunningsworth, A. (1995). Choosing your coursebook. UK: Heinemann English Language Teaching.

Daud, A., \&Celce-Murcia , M. (1979). Selecting and evaluating textbooks. In M. Celce- Murcia \& L. McIntosh (Eds.), Teaching English as a second or foreign Language. New York, NY: Newbury House.

EslamiRasekh, A., Esmae'li, S., Ghavamnia, M., \&Rajabi, S. (2010). Don't Judge a Book by its Cover: Text Book Evaluation in the EFL Settings. The Journal of International Social Research, 3(14), 448- 461.

Garinger, D. (2002). Textbook Selection for the EFL Classroom. Washington DC: ERIC Digest (Dec.).

Hutchinson, T. \& Torres, E. (1994). The Textbook as Agent of Change. ELT Journal, 48(4), 315-328.

Hutchinson, T., \& Waters, A. (1987). English for specific purposes: A learning-centered approach. Cambridge: Cambridge University Press.

Kiely, R. (2009). Small answers to the big question: Learning from language program evaluation. Language Teaching Research, 13(1), 99-116.

Lamie, J. M. (1999). Making the textbook more communicative. The Internal TESL Journal, 5(1). Retrieved September 27, 2012, from www.iteslj.org.

Litz, D. R. A. (2005). Textbook evaluation and ELT management: a South Korean 46 Iranian EFL Journal case study. Asian EFL Journal. Retrieved from: http://www.asian-efl-journal.com/Litz thesis.pdf

Low, G. (1989). Appropriate design: the internal design of course units. Cambridge: Cambridge University Press.

McDonough, J., \& Shaw, C. (2003). Materials and methods in ELT. Oxford: Blackwell.

McGrath, I. (2002). MaterialsEvaluation and Design for Language Teaching. Edinburgh: Edinburgh University Press.

NajafiSarem, S., Hamidi, H., \&Mahmoudie, R. (2013). A Critical Look at Textbook Evaluation: A Case Study of Evaluating an ESP Course-Book: English for International Tourism. International Research Journal of Applied and Basic Sciences, 4 (2), 372-380. 
Nooreen, N., \& Arshad, A. A. (2010). Examining the importance of EST and ESL textbooks and materials: objectives, content and form. [Online] Available: http://www.esp-world.info/Articles_9/textbooks.htm (January 23, 2011)

Razmjoo, S. A. (2007). High schools or private institutes textbooks? Which fulfill communicative language teaching principles in the Iranian context? Asian EFL Journal, 9(4), 126-140.

Rezaee, A. A., Kouhpaeenejad, M. H., \&Mohammadi, A. (2013). Iranian EFL learners' Perspectives on New Interchange series and Top-Notch series: A comparative study. Procedia - Social and Behavioral Sciences 70, 827 - 840.

Richards, J. C. (2001). Curriculum Development in Language Teaching. Cambridge: Cambridge University Press.

Richards, J. C., Platt, J., \& Weber, H. (1985). Longman dictionary of applied linguistics. London: Longman.

Shatery, H. \&Azargoon, M. (2012). Designing and Developing a Native Checklist to Evaluate General English Course Books in Iran and Comparing It with Other Existing Checklists in the World. The First Conference on Language Learning and Teaching: An Interdisciplinary Approach, October, 30 and 31, 2012.

Sheldon, L. (1988). Evaluating ELT textbooks and materials. English Language Teaching Journal, 42(4), 237-246.

Skierso, A. (1991) . Textbook selection and evaluation. In M. Celce-Murcia (Ed.), Teaching English as a second or foreign Language. (pp :) Boston :Heinle and Heinle Publishers.

Soori, A., Kafipour, R., \&Soury, M. (2011). EFL textbook evaluation and graphic representation. European Journal of Social Sciences, 26 (3), 481-493.

Tomlinson, B. (1998). Glossary of basic terms for materials development in language teaching and introduction. In B. Tomlinson (ed.), Materials development inlanguage teaching. (pp. 1-24). Cambridge: Cambridge University Press.

Tomlinson, B. (2001). Materials development. In R. Carter and D. Nunan (Ed.), The Cambridge Guide to Teaching English to Speakers of Other Languages. Cambridge: Cambridge University Press.

Ur, P. (1996). A course in language teaching: Practice and theory. Cambridge: Cambridge University Press. 